\title{
Source attribution using FLEXPART and carbon monoxide emission inventories: SOFT-IO version 1.0
}

\author{
Bastien Sauvage $^{1}$, Alain Fontaine ${ }^{1}$, Sabine Eckhardt ${ }^{3}$, Antoine Auby ${ }^{4}$, Damien Boulanger ${ }^{2}$, Hervé Petetin $^{1}$, \\ Ronan Paugam $^{5}$, Gilles Athier ${ }^{1}$, Jean-Marc Cousin ${ }^{1}$, Sabine Darras ${ }^{3}$, Philippe Nédélec ${ }^{1}$, Andreas Stohl ${ }^{3}$, \\ Solène Turquety ${ }^{6}$, Jean-Pierre Cammas ${ }^{7}$, and Valérie Thouret ${ }^{1}$ \\ ${ }^{1}$ Laboratoire d'Aérologie, Université de Toulouse, CNRS, UPS, France \\ ${ }^{2}$ Observatoire Midi-Pyrénées, Toulouse, France \\ ${ }^{3}$ NILU, Norwegian Institute for Air Research, Kjeller, Norway \\ ${ }^{4}$ CAP HPI, Leeds, United Kingdom \\ ${ }^{5}$ King's College, Dept. Geog, London, United Kingdom \\ ${ }^{6}$ Laboratoire de Météorologie Dynamique/IPSL, UPMC Univ. Paris 6, Paris, France \\ ${ }^{7}$ Observatoire des Sciences de l'Univers de la Réunion (UMS 3365) et Laboratoire de l'Atmosphère et des Cyclones \\ (UMR 8105), Université de la Réunion, Saint-Denis, La Réunion, France
}

Correspondence: Bastien Sauvage (bastien.sauvage@aero.obs-mip.fr)

Received: 12 July 2017 - Discussion started: 26 July 2017

Revised: 27 October 2017 - Accepted: 8 November 2017 - Published: 22 December 2017

\begin{abstract}
Since 1994, the In-service Aircraft for a Global Observing System (IAGOS) program has produced in situ measurements of the atmospheric composition during more than 51000 commercial flights. In order to help analyze these observations and understand the processes driving the observed concentration distribution and variability, we developed the SOFT-IO tool to quantify source-receptor links for all measured data. Based on the FLEXPART particle dispersion model (Stohl et al., 2005), SOFT-IO simulates the contributions of anthropogenic and biomass burning emissions from the ECCAD emission inventory database for all locations and times corresponding to the measured carbon monoxide mixing ratios along each IAGOS flight. Contributions are simulated from emissions occurring during the last 20 days before an observation, separating individual contributions from the different source regions. The main goal is to supply added-value products to the IAGOS database by evincing the geographical origin and emission sources driving the $\mathrm{CO}$ enhancements observed in the troposphere and lower stratosphere. This requires a good match between observed and modeled CO enhancements. Indeed, SOFT-IO detects more than $95 \%$ of the observed CO anomalies over most of the regions sampled by IAGOS in the troposphere. In the majority of cases, SOFT-IO simulates $\mathrm{CO}$ pollution
\end{abstract}

plumes with biases lower than 10-15 ppbv. Differences between the model and observations are larger for very low or very high observed $\mathrm{CO}$ values. The added-value products will help in the understanding of the trace-gas distribution and seasonal variability. They are available in the IAGOS database via http://www.iagos.org. The SOFT-IO tool could also be applied to similar data sets of CO observations (e.g., ground-based measurements, satellite observations). SOFT-IO could also be used for statistical validation as well as for intercomparisons of emission inventories using large amounts of data.

\section{Introduction}

Tropospheric pollution is a global problem caused mainly by natural or human-triggered biomass burning and anthropogenic emissions related to fossil fuel extraction and burning. Pollution plumes can be transported quickly on a hemispheric scale (within at least 15 days) by large-scale winds or, more slowly (Jacob, 1999), between the two hemispheres (requiring more than 3 months). Global anthropogenic emissions are for some species $\left(\mathrm{CO}_{2}\right)$ constantly increasing (Boden et al., 2015). However, recent commit- 
ments of some countries to reduce greenhouse gas emissions (e.g., over the US; US EPA's Inventory of US Greenhouse Gas Emissions and Sinks, 1990-2013; http://www.epa.gov/ climatechange/ghgemissions/usinventoryreport.html) seems to induce a stalling in other global emissions $\left(\mathrm{NO}_{x}, \mathrm{SO}_{2}\right.$ and black carbon; Stohl et al., 2015), except for those regions (Brazil, Middle East, India, China) where $\mathrm{NO}_{x}$ emissions increase (Miyazaki, 2017). In order to better understand largescale pollution transport, large amounts of in situ and spacebased data have been collected in the last three decades, allowing a better understanding of pollution variability and its connection with atmospheric transport patterns (e.g., Liu et al., 2013). These data sets are also useful to quantify global pollution evolution with respect to the emission trends described above.

Despite the availability of large trace gas data sets, the data interpretation remains difficult for the following reasons: (1) the sampling mode does not correspond to an a priori defined scientific strategy, in contrast to data collected during field campaigns; (2) the statistical analysis of the data can be complicated by the large number of different sources contributing to the measured pollution, and an automated analysis of the contributions from these different sources is required if, for instance, regional trends in emissions are to be investigated; (3) the sheer size of some of the data sets can make the analysis rather challenging. Among the longterm pollution measurement programs, the IAGOS airborne program (http://www.iagos.org/, formerly known as the Measurement of OZone by Airbus In-service airCraft - MOZAIC - program) is the only one delivering in situ measurement data from the free troposphere. IAGOS has provided regular global measurements of ozone $\left(\mathrm{O}_{3}\right)$ since 1994, carbon monoxide (CO) since 2002, and nitrogen oxides $\left(\mathrm{NO}_{y}\right)$ for the period 2001-2005 obtained during more than 51000 commercial aircraft flights, with substantial extension of the instrumented aircraft recently. The analysis of the IAGOS database is also complicated by the fact that primary pollutants $\left(\mathrm{CO}\right.$ and part of $\left.\mathrm{NO}_{y}\right)$ are emitted by multiple sources, while secondary compounds $\left(\mathrm{O}_{3}\right)$ are produced by photochemical transformations of these pollutants, often most efficiently when pollutants from different sources mix.

A common approach to separate the different sources influencing trace gas observations is based on the determination of the air mass origins through Lagrangian modeling. This approach allows linking the emission sources to the trace gas observations (e.g., Nédélec et al., 2005; Sauvage et al., 2005, 2006; Tressol et al., 2008; Gressent et al., 2014; Clark et al., 2015; Yamasoe et al., 2015). Lagrangian modeling of the dispersion of particles allows accounting efficiently for processes such as large-scale transport, turbulence and convection. When coupled with emission inventories, Lagrangian modeling of passive tracers allows for instance to understand ozone anomalies (Cooper et al., 2006; Wen et al., 2012), to quantify the importance of lightning $\mathrm{NO}_{x}$ emissions for tropospheric $\mathrm{NO}_{2}$ columns measured from space
(Beirle et al., 2006), to investigate the origins of $\mathrm{O}_{3}$ and $\mathrm{CO}$ over China (Ding et al., 2013) or to investigate the sources influencing the observed $\mathrm{CO}_{2}$ over the high northern latitudes (Vay et al., 2011).

To help analyze a large data set such as the IAGOS observations, it is important to provide scientific users with a tool for characterizing air mass transport and emission sources. This study presents a methodology to systematically establish a link between emission sources (biomass burning and anthropogenic emissions) and concentrations at the receptor locations. Since CO is a substance that is emitted by combustion sources (both anthropogenic and biomass burning) and has a lifetime of months in the troposphere (Logan et al., 1981; Mauzerall et al., 1998), it is often used as a tracer for pollution transport (Staudt et al., 2001; Yashiro et al., 2009; Barret et al., 2016). It is therefore convenient to follow past examples and use simulated $\mathrm{CO}$ source contributions to gauge the influence of pollution sources on the measurements also with SOFT-IO. Our methodology uses the FLEXPART Lagrangian particle dispersion model (Stohl et al., 2005) and emission inventories from the Emissions of atmospheric Compounds \& Compilation of Ancillary Data (ECCAD) emission database (Granier et al., 2012) in order to quantify the influence of emission sources on the IAGOS $\mathrm{CO}$ measurements. The goal is to provide the scientific community with added-value products that will help them analyze and interpret the large number of IAGOS measurements. The methodology is focused on the development of a scientific tool (SOFT-IO version 1.0) based on FLEXPART particle dispersion model, that simulates the contributions of anthropogenic and biomass burning emissions for IAGOS $\mathrm{CO}$ measurements. This tool, which has the benefit of being adaptable to multiple emission inventories without rerunning FLEXPART simulations, is described and then evaluated in the present study with the large data sets of IAGOS CO measurements. SOFT-IO could in the future be easily adapted and used to analyze other data sets of trace gas measurements such as from ground-based observations, sondes, aircraft campaigns or satellite observations.

The methodology will be described in the next section and then evaluated at the example of case studies of pollution plumes observed by IAGOS aircraft. Further evaluation is performed through statistical analysis. Finally we discuss the limitations of the methodology by estimating its sensitivity to different input data sets (emission inventories, meteorological analyses).

\section{In situ observations database: MOZAIC and IAGOS programs}

The MOZAIC program (Marenco et al., 1998) was initiated in 1993 by European scientists, aircraft manufacturers and airlines to better understand the natural variability of the chemical composition of the atmosphere and how it is 
changing under the influence of human activity, with particular interest in the impact of aircraft exhaust. Between August 1994 and November 2014, MOZAIC performed airborne in situ measurements of ozone, water vapor, carbon monoxide and total nitrogen oxides. The measurements are geolocated (latitude, longitude and pressure) and come along with meteorological observations (wind direction and speed, temperature). Data acquisition is performed automatically during round-trip international flights (ascent, descent and cruise phases) from Europe to America, Africa, Middle East and Asia (Fig. 1).

Based on the technical expertise of MOZAIC, the IAGOS program (Petzold et al., 2015, and references therein) has taken over and provided observations since July 2011. The IAGOS data set still includes ozone, water vapor, carbon monoxide and meteorological observations, and measurements of cloud droplets (number and size) are also performed. Depending on optional additional instrumentation, measurements of nitrogen oxides, total nitrogen oxides and, in the near future, greenhouse gases $\left(\mathrm{CO}_{2}\right.$ and $\left.\mathrm{CH}_{4}\right)$ and aerosols will also be made.

Since 1994, the IAGOS-MOZAIC observations have created a big data set that is stored in a single database holding data from more than 51000 flights. The data set can be used by the entire scientific community, allowing studies of chemical and physical processes in the atmosphere as well as validation of global chemistry transport models and satellite retrievals. Most of the measurements have been collected in the upper troposphere (UT) and lower stratosphere, between 9 and $12 \mathrm{~km}$ altitude, with 500 flights per aircraft per year on up to 7 aircraft.

The MOZAIC and IAGOS data (called simply IAGOS from here on) used in this study are in situ observations of $\mathrm{CO}$ only, which is being measured regularly on every aircraft since 2002 with more than 30000 flights, using a modified infrared filter correlation monitor (Nédélec et al., 2003, 2015). The accuracy of the CO measurements has been estimated at ( $30 \mathrm{~s}$ response time) $\pm 5 \mathrm{ppb}$, or $\pm 5 \%$.

Several case studies of CO pollution plumes (Table 1) using IAGOS data have been published, where model simulations allowed attribution of the measured $\mathrm{CO}$ enhancements to anthropogenic or biomass burning emissions, measured either in the planetary boundary layer (PBL) or in the free troposphere, following regional- or synoptic-scale transport (e.g., Nédélec et al., 2005; Tressol et al., 2008; Cammas et al., 2009; Elguindi et al., 2010). These case studies are used here to better define the requirements for our methodology (meteorological analyses and emission inventory inputs). Some of them are detailed and reanalyzed in Sect. 4.

\section{Estimation of carbon monoxide source regions: methodology}

To establish systematic source-receptor relationships for IAGOS observations of $\mathrm{CO}$, the Lagrangian dispersion model FLEXPART (Stohl et al., 1998, 2005; Stohl and Thomson, 1999 ) is run over the entire database. Lagrangian dispersion models usually represent the differential advection better than global Eulerian models (which do not resolve intercontinental pollution transport well; Eastham et al., 2017), at a significantly lower computational cost. In particular, smallscale structures in the atmospheric composition can often be reconstructed from large-scale global meteorological data, which makes model results comparable to high-resolution in situ observations (Pisso et al., 2010). In the past, many studies (Nédélec et al., 2005; Tressol et al., 2008; Cammas et al., 2009; Elguindi et al., 2010; Gressent et al., 2014) used FLEXPART to investigate specific pollution events observed by the IAGOS aircraft. However, in these case studies, the link between sources and observations of pollution was hypothesized a priori. The transport model was then used to validate the hypothesis. For example, in the Cammas et al. (2009) study, observations of high CO during summer in the upper troposphere and lower stratosphere east of Canada were guessed to originate from biomass burning over Canada as this region is often associated with pyro-convection, the intensity of which usually peaks in the summer. This origin was confirmed by the model analysis. In general, the origin of the observed pollution cannot be hypothesized a priori, especially when analyzing measurements from thousands of flights. Moreover, most of the time multiple sources are involved when the observed pollution is the result of the mixing of polluted air masses from different regions and source types.

$\mathrm{CO}$ is often used as a tracer to quantify the contributions of the different sources to the observed pollution episodes. $\mathrm{CO}$ is emitted by both the combustion of fossil fuels and by biomass burning, and its photochemical lifetime against $\mathrm{OH}$ attack is usually 1 to 2 months in the troposphere (Logan et al., 1981; Mauzerall et al., 1998). Therefore it is possible to link elevated CO mixing ratios (with respect to its seasonally varying hemispheric baseline) to pollution sources without simulating the atmospheric chemistry.

\subsection{Backward transport modeling}

Simulations were performed using the version 9 of FLEXPART, which is described in detail by Stohl et al. (2005, and references therein). The model was driven using wind fields from the European Centre for Medium-Range Weather Forecast (ECMWF) 6-hourly operational analyses and $3 \mathrm{~h}$ forecasts. The ECMWF data are gridded with a $1^{\circ} \times 1^{\circ}$ horizontal resolution, and with a number of vertical levels increasing from 60 in 2002 to 137 since 2013. The model was also tested using higher horizontal resolution $\left(0.5^{\circ}\right)$ and with ECMWF 


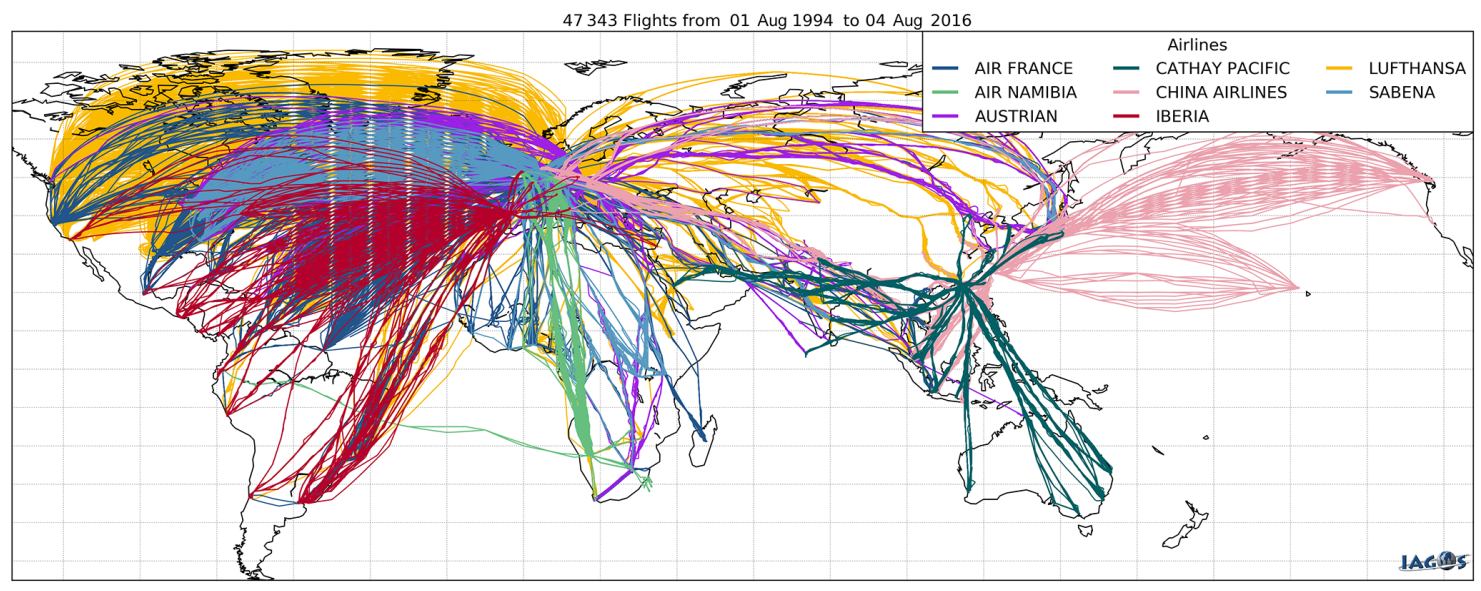

Figure 1. Map showing all flights performed by the IAGOS program.

Table 1. Case studies used to define model settings. Cases studies discussed in the paper are in bold.

\begin{tabular}{llll}
\hline Date & Takeoff & Landing & Used for choosing \\
\hline 10 March 2002 & Frankfurt & Denver & Anthropogenic emission inventories \\
27 November 2002 & Dallas & Frankfurt & Anthropogenic emission inventories \\
4 June 2003 & Tokyo & Vienna & Fire injection heights (pyro-convection) \\
6 August 2003 & Boston & Frankfurt & Fire injection heights \\
9 August 2003 & Dubai & Frankfurt & Fire injection heights \\
10 August 2003 & Frankfurt & Dallas & Fire injection heights \\
29 June 2004 & Caracas & Frankfurt & Fire injection heights (pyro-convection) \\
30 June 2004 & Frankfurt & Washington & Fire injection heights (pyro-convection) Fire inventories \\
22 July 2004 & Frankfurt & Atlanta & Fire injection heights (pyro-convection) Fire inventories \\
22 July 2004 & Douala & Paris & Fire injection heights (pyro-convection)Fire inventories \\
23 July 2004 & Frankfurt & Atlanta & Fire injection heights (pyro-convection) n Fire inventories \\
19 July 2005 & Munich & Hong Kong & Anthropogenic emission inventories \\
22 October 2005 & Munich & Hong Kong & Anthropogenic emission inventories \\
30 July 2008 & Windhoek & Frankfurt & Fire injection heightsFire emission inventories \\
31 July 2008 & Frankfurt & Windhoek & Fire injection heights Fire emission inventories \\
\hline
\end{tabular}

ERA-Interim reanalysis, as their horizontal and vertical resolution and model physics are homogeneous during the whole period of IAGOS CO measurements. However, operational analyses were used for our standard setup, as the transport model reproduced $\mathrm{CO}$ better when using these data for several case studies of pollution transport, especially for plumes located in the UT. Indeed, operational analyses provide a better vertical resolution since 2006 (91 levels until 2013, then 137 levels against 60 levels for ERA-Interim) and thus a better representation of the vertical wind shear, and the underlying meteorological model is also more modern than the one used for producing ERA-Interim. Vertical resolution is one of the critical factors for modeling such $\mathrm{CO}$ plumes with the best precision in terms of location and intensity (Eastham and Jacob, 2017).

Using higher horizontal resolution for met field analyses and forecasts $\left(0.5\right.$ vs $\left.1^{\circ}\right)$ showed no influence on the simulated carbon monoxide, despite larger computational time and storage needs. We assume further improvement can be obtained using even higher horizontal resolution $\left(0.1^{\circ}\right)$, but this was not feasible at this stage and should be considered in the future.

In order to be able to represent the small-scale structures created by the wind shear and observed in many IAGOS vertical profiles, the model is initialized along IAGOS flight tracks every $10 \mathrm{hPa}$ during ascents and descents and every $0.5^{\circ}$ in latitude and longitude at cruise altitude. This procedure leads to $i$ model initialization boxes along every flight track. For each $i, 1000$ particles are released. Indeed, 1000 to 6000 particles are suggested for correct simulations in similar studies based on sensitivity tests on particles number (Wen et al., 2012; Ding et al., 2013). For instance, a Frankfurt (Germany) to Windhoek (Namibia) flight contains around 290 boxes (290000 particles) of initialization as a whole.

FLEXPART is set up for backward simulations (Seibert and Frank, 2004) from these boxes as described in Stohl et 
al. (2003) and backward transport is computed for 20 days prior to the in situ observation, which is sufficient to consider hemispheric-scale pollution transport in the midlatitudes (Damoah et al., 2004; Stohl et al., 2002; Cristofanelli et al., 2013). This duration is also expected to be longer than the usual lifetime of polluted plumes in the free troposphere, i.e., the time when the concentration of pollutants in plumes is significantly larger than the surrounding background. Indeed, the tropospheric mixing timescale has been estimated to be typically shorter than 10 days (Good et al., 2003; Pisso et al., 2009). Therefore the model is expected to be able to link air mass anomalies such as strong enhancements in $\mathrm{CO}$ to the source regions of emissions (Stohl et al., 2003). It is important to note that we aim to simulate recent events of pollution explaining $\mathrm{CO}$ enhancements over the background but not to simulate the $\mathrm{CO}$ background which results from aged and well-mixed emissions.

The FLEXPART output is a residence time, as presented and discussed in Stohl et al. (2003). These data represent the average time spent by the transported air masses in a grid cell, divided by the air density, and are proportional to the sensitivity of the receptor mixing ratio to surface emissions. In our case, it is calculated for every input point along the flight track, every day for $N_{t}=20$ days backward in time, on a $1^{\circ}$ longitude $\times 1^{\circ}$ latitude global grid with $N_{z}=12$ vertical levels (every $1 \mathrm{~km}$ from 0 to $12 \mathrm{~km}$, and 1 layer above $12 \mathrm{~km}$ ).

Furthermore, the altitude of the $2 \mathrm{PVU}$ (potential vorticity units) above or below the flight track is extracted from the wind and temperature fields in order to locate the $\mathrm{CO}$ observations above or below the dynamical tropopause according to the approach of Thouret et al. (2006).

\subsection{Emission inventories from the ECCAD project}

The main goal of the ECCAD project (Granier et al., 2012) is to provide scientific and policy users with data sets of surface emissions of atmospheric compounds and ancillary data, i.e., data required for estimating or quantifying surface emissions. All the emission inventories and ancillary data provided by ECCAD are published in the scientific literature.

For the current study, we selected five $\mathrm{CO}$ emission inventories. Four of them are available at global-scale (MACCity and EDGAR v4.2 for anthropogenic; GFED 4 and GFAS v1.2 - GFAS v1.0 for 2002 - for fires) from the ECCAD database and cover most of the IAGOS CO database presented here (2002-2013). The global-scale inventories have a $0.1^{\circ} \times 0.1^{\circ}$ to $0.5^{\circ} \times 0.5^{\circ}$ horizontal resolution. They are provided with daily, monthly or yearly time resolution. They are listed in Table 2 along with the references describing them. The four global inventories are used to study the model's performance and sensitivity in Sect. 5 .

To further test the sensitivity to the emission inventories, we also used one regional inventory, which is expected to provide a better representation of emissions in its region of interest than generic global inventories. The aim is to test the ability of regional inventories in better representing simulated CO for specific case studies. The goal of using regional data set in this paper is only to evaluate the incidence of one of them respect to global emission inventories, not to evaluate the incidence of all regional data set. We have chosen the International Consortium for Atmospheric Research on Transport and Transformation (ICARTT) campaign because of improved results demonstrated in the representation of boreal biomass burning fires in some specific cases (Turquety et al., 2016) as, for example, the one based on MOZAIC data by Elguindi et al. (2010). Global emission inventories are the first choice to interpret quasi-global coverage of the CO IAGOS measurements. In the future we plan to include regional emission inventories for the study of specific events. For biomass burning, ICARTT's North American emission inventory developed by Turquety et al. (2007) for the summer of 2004 and provided at $1^{\circ} \times 1^{\circ}$ horizontal resolution was tested. It combines daily area burned data from forest services with the satellite data used by global inventories and uses a specific vegetation database, including burning of peat lands, which represents a significant contribution to the total emissions.

\subsection{Coupling transport output with $\mathrm{CO}$ emissions}

Calculating the recent contributions $C(i)\left(\mathrm{kg} \mathrm{m}^{-3}\right)$ of $\mathrm{CO}$ emissions for every one of the $i$ model's initialization points along the flight tracks requires three kinds of data:

- the residence time $T_{\mathrm{R}}$ (in seconds, gridded with $N_{x}=$ 360 by $N_{y}=180$ horizontal points, $N_{z}=12$ vertical levels, $N_{t}=20$ days) from backward transport described in Sect. 3.1;

$-\underset{\left.\mathrm{kg} \mathrm{CO} \mathrm{m}^{-2} \mathrm{~s}^{-1}\right) ;}{\mathrm{CO}}$ surface emissions $E_{\mathrm{CO}}\left(N_{x}, N_{y}, N_{t}\right)$

- the injection profile $\operatorname{Inj}(z)$ defining the fraction of pollutants diluted in the different vertical levels (with $\Delta z$ being the thickness, in meters); just after emissions and defined according to three different approaches (DENTENER, MIXED or APT) described in the next paragraph:

$$
\begin{aligned}
C(i)= \\
\sum_{t=1}^{N_{t}} \sum_{y=1}^{N_{y}} \sum_{x=1}^{N_{x}} \sum_{z=1}^{N_{z}} \operatorname{Inj}(z) \frac{T_{\mathrm{R}}(x, y, z, t, i) E_{\mathrm{CO}}(x, y, t)}{\Delta z(z)} .
\end{aligned}
$$

In the case of anthropogenic emissions, $\mathrm{CO}$ is simply emitted into the first vertical layer of the residence time grid $(\Delta z=$ $1000 \mathrm{~m}$ ).

For biomass burning emissions, in the tropics and midlatitude regions, the lifting of biomass burning plumes is usually due to small- and large-scale dynamical processes, such 
Table 2. List of emission inventories used in this study.

\begin{tabular}{lllll}
\hline Inventory & Temporal coverage & Horizontal resolution & Temporal resolution & Reference \\
\hline \multicolumn{2}{l}{ Anthropogenic emissions } & & \\
\hline MACCity & $1960-2014+$ & $0.5^{\circ} \times 0.5^{\circ}$ & Monthly & Lamarque et al. (2010); Granier et al. (2011) \\
EDGAR v4.2 & $1970-2008$ & $0.5^{\circ} \times 0.5^{\circ}$ & Yearly & Janssens-Maenhout et al. (2010) \\
\hline Biomass burning emissions & & & Giglio et al. (2013) \\
\hline GFED 4 & $1997-2017+$ & $0.5^{\circ} \times 0.5^{\circ}$ & Daily & Kaiser et al. (2012) \\
GFAS v1.0 & 2002 & $0.5^{\circ} \times 0.5^{\circ}$ & Daily & Turquety et al. (2007) \\
GFAS v1.2 & $2003-2017+$ & $0.1^{\circ} \times 0.1^{\circ}$ & Daily & Daily \\
ICARTT & 2004 & $1^{\circ} \times 1^{\circ}$ & . & \\
\hline
\end{tabular}

as turbulence in the PBL, deep convection and frontal systems, which are usually represented by global meteorological models. At higher latitudes, however, boreal fires can also be associated with pyro-convection and quick injection above the PBL, even if CO tends to be mostly released during smoldering. Pyro-convection plume dynamics are often associated with small-scale processes that are not represented in global meteorological data and emission inventories (Paugam et al., 2016). In order to characterize the effect of these processes, we implemented three methodologies to parameterize biomass injection height:

- The first one (named DENTENER) depends only on the latitude and uses constant homogeneous injection profiles as defined by Dentener et al. (2006), i.e., $0-1 \mathrm{~km}$ for the tropics $\left(30^{\circ} \mathrm{S}-30^{\circ} \mathrm{N}\right.$; see green line in Fig. 2), $0-2 \mathrm{~km}$ for the midlatitudes $\left(60-30^{\circ} \mathrm{S}, 30-60^{\circ} \mathrm{N}\right.$; see blue line in Fig. 2) and $0-6 \mathrm{~km}$ for the boreal regions (90-60 $\mathrm{S}, 60-90^{\circ} \mathrm{N}$; not shown in Fig. 2).

- The second (named MIXED) uses the same injection profiles as in DENTENER for the tropics and midlatitudes, but injection profiles for the boreal forest are deduced from a lookup table computed with the plume rise model PRMv2 presented in Paugam et al. (2015). Using PRMv2 runs for all fires from different years of the North American MODIS archive, three daily fire radiative power (FRP) classes (under $10 \mathrm{TJ} \mathrm{day}^{-1}$, between 10 and $100 \mathrm{TJ} \mathrm{day}^{-1}$ and over $100 \mathrm{TJ} \mathrm{day}^{-1}$ ) were used to identify three distinct injection height profiles (see brown, red, and black lines in Fig. 2). Although PRMv2 reflects both effects of the fire intensity through the input of FRP and active fire size and effects of the local atmospheric profile, for the sake of simplicity only FRP is used here to classify the injection profile. Furthermore, when applied to the IAGOS data set, the MIXED method uses equivalent daily FRP estimated from the emitted CO fluxes given by the emission inventories as described in Kaiser et al. (2012).

- The third method (named APT) uses a homogeneous profile defined by the daily plume top altitude as es-

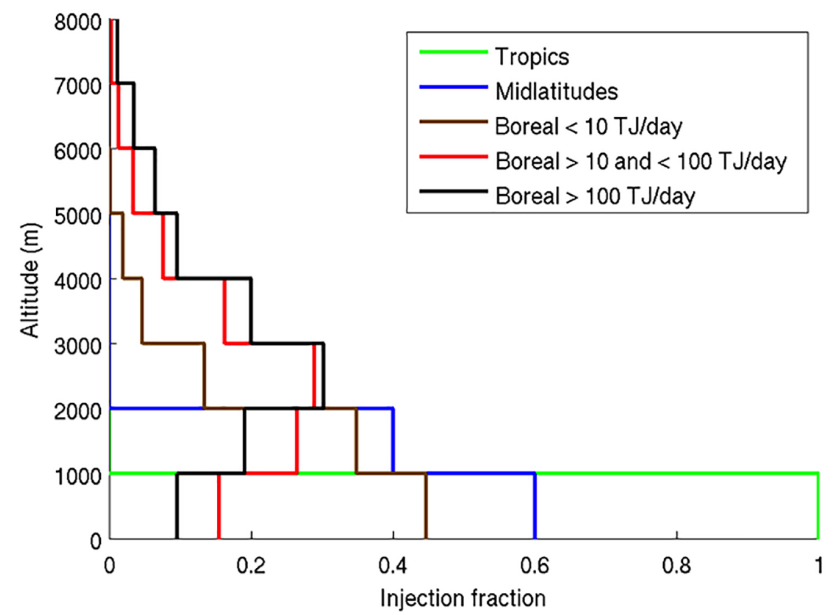

Figure 2. Injection profiles used for biomass burning emissions for different regions (tropics, midlatitudes, boreal) in the MIXED methodology.

timated for each $0.1 \times 0.1$ pixel of the GFAS v1.2 inventory available for 2003 to 2013 (Rémy et al. 2016, and http://www.gmes-atmosphere.eu/oper_info/global_ nrt_data_access/gfas_ftp/). As in the MIXED method, GFAS v1.2 is using the plume model PRMV2 from Paugam et al. (2015), but here the model is run globally for every assimilated GFAS-FRP pixel.

\subsection{Automatic detection of $\mathrm{CO}$ anomalies}

For individual measurement cases, plumes of pollution can most of the time be identified by the human eye using the observed $\mathrm{CO}$ mixing ratio time series or the $\mathrm{CO}$ vertical profiles. However, this is not feasible for a database of tens of thousands of observation flights. In order to create statistics of the model's performance, we need to systematically identify observed pollution plumes in the IAGOS database. The methodology to do this is based on what has been previously done for the detection of layers in the MOZAIC database (Newell et al., 1999; Thouret et al., 2000), along 

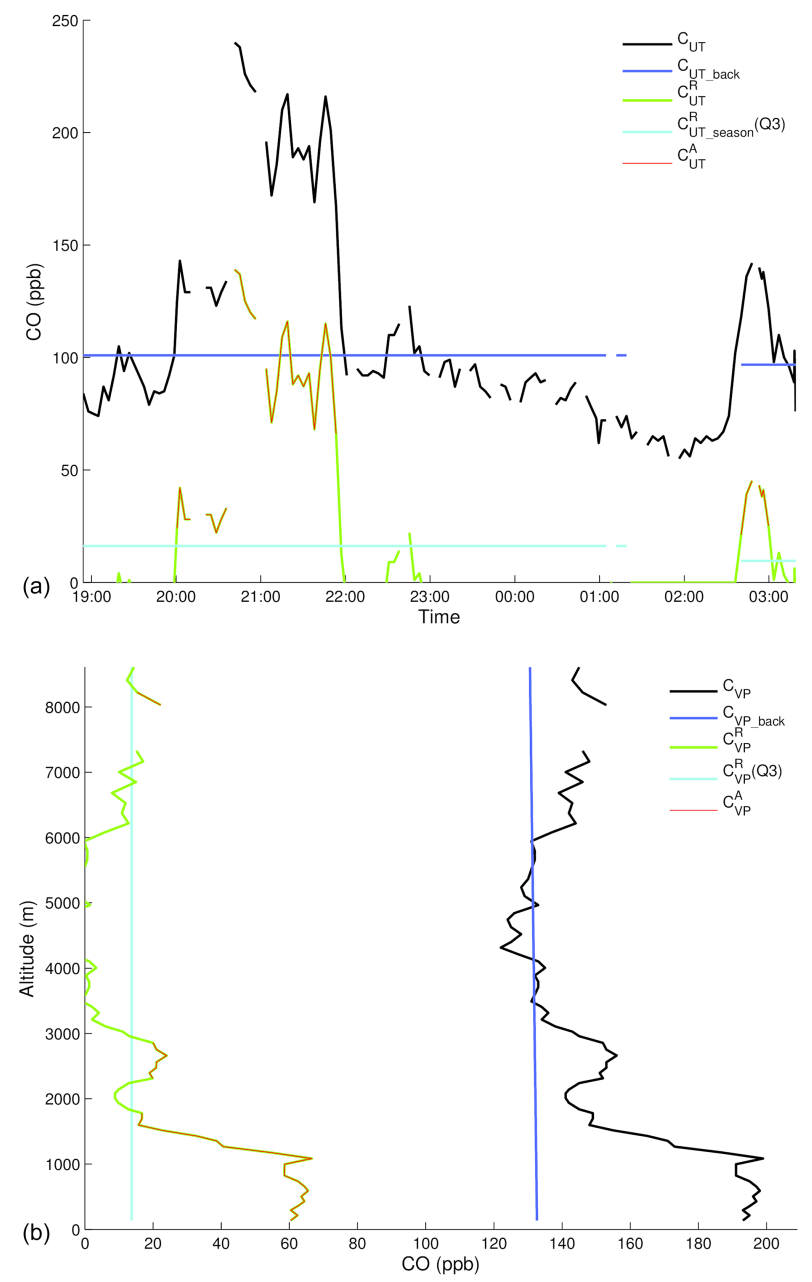

scents and in the upper troposphere and lower stratosphere, respectively. A range of altitudes from the surface to a top altitude identifies vertical profiles. The top altitude is $75 \mathrm{hPa}$ above the 2 PVU dynamical tropopause (Thouret at al., 2006) when the aircraft reaches or leaves cruising altitude (during ascent or descent). The potential vorticity is taken from the ECMWF operational analyses and evaluated at the aircraft position by FLEXPART. Observations made during the cruise phase are flagged as upper tropospheric when the aircraft is below the 2 PVU dynamical tropopause. If not, observations are considered as stratospheric and then are ignored in the rest of the paper. Although CO contributions are calculated also in the stratosphere, the present study focuses on tropospheric pollution only.

In a second step, the $\mathrm{CO}$ background mixing ratio is determined for each tropospheric part $\left(C_{\mathrm{VP} \_ \text {back }}\right.$ and $C_{\mathrm{UT} \_ \text {back }}$; see Fig. 3 for illustration) for the tropospheric vertical profiles and for the upper troposphere, respectively. For tropospheric vertical profiles, the linear regression of $\mathrm{CO}$ mixing ratio versus altitude is calculated from $2 \mathrm{~km}$ to the top of the vertical profiles to account for the usual decrease of background $\mathrm{CO}$ with altitude. Data below $2 \mathrm{~km}$ are not used because high $\mathrm{CO}$ mixing ratios caused by fresh emissions are usually observed close to surface over continents. The slope $a$ (in $\mathrm{ppb} \mathrm{m}^{-1}$ ) of the linear regression is used to determine the background so that $C_{\mathrm{VP} \_ \text {back }}=a Z$. The background is removed from the $C_{\mathrm{VP}}$ tropospheric vertical profiles mixing ratio to obtain a residual $\mathrm{CO}$ mixing ratio $C_{\mathrm{VP}}^{\mathrm{R}}$ (Eq. 2).

$C_{\mathrm{VP}}^{\mathrm{R}}=C_{\mathrm{VP}}-C_{\mathrm{VP} \_ \text {back }}$

For the upper troposphere, the $\mathrm{CO}$ background mixing ratio $\left(C_{\mathrm{UT}}\right.$ back $)$ is determined using seasonal median values (over the entire IAGOS database) for the different regions of Fig. 4. Note that this approach was not feasible for vertical profiles as for most of the visited airports there are not enough data to establish seasonal vertical profiles. As for the profiles, background values are subtracted from the UT data to obtain residual $C_{\mathrm{UT}}^{\mathrm{R}}$ (Eq. 3):

percentiles define for different regions along the IAGOS data set (Gressent et al., 2014). An example demonstrating the procedure, which is described below, is shown in Fig. 3.

In a first step, the measurement time series along the flight track (number of measurements $n_{\text {TOT }}$ ) is separated into three parts:

1. ascent and descent vertical profiles $\left(n_{\mathrm{VP}}\right)$ in the PBL (altitudes ranging from the ground to $2 \mathrm{~km}$ ) and in the free troposphere (from $2 \mathrm{~km}$ to the top altitude of the vertical profiles),

2. measurements at cruising altitude in the upper troposphere $\left(n_{\mathrm{UT}}\right)$, and

3. measurements in the lower stratosphere $\left(n_{\mathrm{LS}}\right)$.

$n_{\mathrm{TOT}}=n_{\mathrm{VP}}+n_{\mathrm{UT}}+n_{\mathrm{LS}}$, where $n_{\mathrm{VP}}, n_{\mathrm{UT}}$ and $n_{\mathrm{LS}}$ are the number of measurements along tropospheric ascents and de-

In a third step, $\mathrm{CO}$ anomalies $C^{\mathrm{A}}$ are determined for tropospheric vertical profiles $\left(C_{\mathrm{VP}}^{\mathrm{A}}\right)$ and in the upper troposphere $\left(C_{\mathrm{UT}}^{\mathrm{A}}\right)$. Residual $C_{\mathrm{VP}}^{\mathrm{R}}$ and $C_{\mathrm{UT}}^{\mathrm{R}}$ values are flagged as $\mathrm{CO}$ anomalies when these values exceed the third quartile (Q3) of the residual mixing ratio $C_{\mathrm{VP}}^{\mathrm{R}}(\mathrm{Q} 3)$ for vertical profiles, or the third quartile of the residual seasonal values $C_{\mathrm{UT}}^{\mathrm{R}}$ season (Q3) in the different regions (Fig. 4) for the UT. Note that $C_{\mathrm{VP}}^{\mathrm{R}}(\mathrm{Q} 3)$ or $C_{\mathrm{UT} \text { _season }}^{\mathrm{R}}(\mathrm{Q} 3)$ needs to be higher than $5 \mathrm{ppb}$ (the accuracy of the CO instrument; Nédélec et al., 2015) in order to consider an anomaly:

$C_{v}^{\mathrm{A}} \mathrm{VP}=C_{\mathrm{VP}}^{\mathrm{R}}$ if $C_{\mathrm{VP}}^{\mathrm{R}}$ it $>C_{\mathrm{VP}}^{\mathrm{R}}(\mathrm{Q} 3)$,

$C_{\mathrm{UT}}^{\mathrm{A}}=C_{\mathrm{UT}}^{\mathrm{R}}$ if $C_{\mathrm{UT}}^{\mathrm{R}}>C_{\mathrm{UT} \_ \text {season }}^{\mathrm{R}}(\mathrm{Q} 3)$.

In the examples shown in Fig. $3 \mathrm{a}$ and $b$, the red line represents $\mathrm{CO}$ anomalies. 


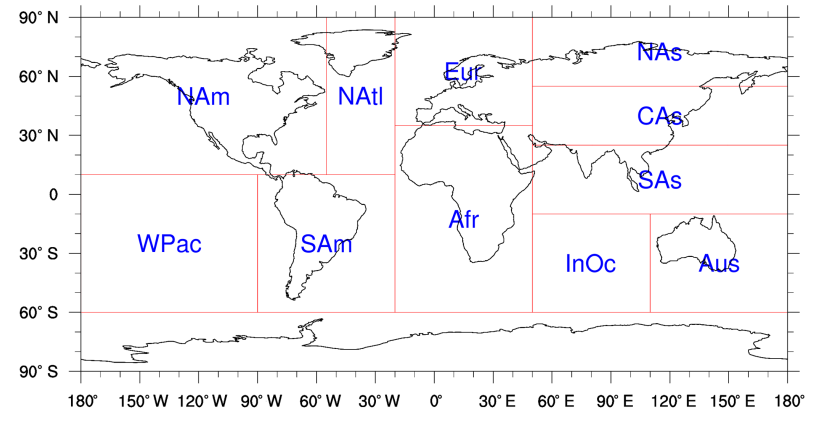

Figure 4. Map of the defined regions used to sort IAGOS CO anomalies.

With this algorithm CO plumes are automatically detected in the entire IAGOS database. For each identified plume, minimum and maximum values of the date, latitude, longitude and altitude, as well as the $\mathrm{CO}$ mean and maximum mixing ratio, are archived. These values are used for comparison with modeled $\mathrm{CO}$ values.

\section{Selected case studies to evaluate $\mathrm{CO}$ emission inventories and SOFT-IO's performance}

As described in Sect. 2, a number of case studies documented in the literature were selected from the IAGOS database in order to get a first impression of the model's performance. These case studies have been chosen to represent the different pollution situations that are often encountered in the troposphere in terms of emissions (anthropogenic or biomass burning) and transport (at regional or synoptic scale, pyroconvection, deep convection, frontal systems). Systematic evaluation of the model performance against emission inventories will be presented in Sect. 5 .

\subsection{Anthropogenic emission inventories}

Among the case studies listed in Table 1, four were selected in order to illustrate the evaluation of the inventories used for anthropogenic emissions. Landing profiles over Hong Kong from 19 July and 22 October 2005 were selected in order to investigate specifically Asian anthropogenic emissions. During the 10 March 2002 Frankfurt-Denver and 27 November 2002 Dallas-Frankfurt flights, IAGOS instruments observed enhanced CO plumes in the North Atlantic upper troposphere, also linked to anthropogenic emissions. Figure 5a shows the observed (black line) and simulated (colored lines) CO mixing ratios above Hong Kong during 22 October 2005. Note that background is not simulated but estimated from the observations as described in Sect 3.4 (blue line, $C_{\mathrm{VP} \_b a c k}$ ). The dashed blue line represents the residual $\mathrm{CO}$ mixing ratio $C_{\mathrm{VP}}^{\mathrm{R}}$. Observations show little variability in the free troposphere down to around $3 \mathrm{~km}$. Strong pollution is observed below, with $+300 \mathrm{ppb}$ enhancement over the background on average between 0 and $3 \mathrm{~km}$. Note that we do not discuss $\mathrm{CO}$ enhancement above $3 \mathrm{~km}$.

In agreement with $C_{\mathrm{VP}}^{\mathrm{R}}$, SOFT-IO simulates a strong CO enhancement in the lowest $3 \mathrm{~km}$ of the profile, caused by fresh emissions. However, the simulated enhancement is less strong than the observed one, a feature that is typical for this region, as we shall see later.

In addition to the $\mathrm{CO}$ mixing ratio, SOFT-IO calculates $\mathrm{CO}$ source contributions and geographical origins of the modeled $\mathrm{CO}$ displayed, respectively, in Fig. 5b and c (using the methodology described in Sect. 3.4) and using here MACCity and GFAS v1.2 as examples. For the geographical origin we use the same 14 regions as defined for the GFED emissions (http://www.globalfiredata.org/data.html). Note that only the average of the calculated CO is displayed for each anomaly $(0-3 \mathrm{~km} ; 3.5-6 \mathrm{~km})$ in Fig. $5 \mathrm{~b}$ and c.

Colored lines in Fig. 5a show the calculated CO using anthropogenic sources described by the two inventories selected in Sect. 3.2, MACCity (green line) and EDGARv4.2 (yellow line), along the flight track. In both cases, biomass burning emissions are described by GFAS v1.2. Emissions from fires have negligible influence (less than $3 \%$ ) on this pollution event as depicted in Fig. 5b.

In the two simulations, the calculated $\mathrm{CO}$ mixing ratio is below $50 \mathrm{ppb}$ in the free troposphere, as we do not simulate background concentrations with SOFT-IO. CO enhancement around 4 to $6 \mathrm{~km}$ is overestimated by SOFT-IO. CO above $6 \mathrm{~km}$ is not considered as an anomaly, as $C_{\mathrm{UT}}^{\mathrm{R}}<C_{\mathrm{UT} \text { _season }}^{\mathrm{R}}$ (Q3). Simulated mixing ratios in the $0-2 \mathrm{~km}$ polluted layer are almost homogeneous, with values around $280 \mathrm{ppb}$ using MACCity and around $160 \mathrm{ppb}$ using EDGARv4.2. They are attributed to anthropogenic emissions (more than $97 \%$ of the simulated $\mathrm{CO}$ ) originating mostly from central Asia with around $95 \%$ influence. In this regard, the CO simulated using MACCity is in better agreement with the observed CO than the one obtained using EDGARv4.2. Indeed, using MACCity, simulated CO reaches $90 \%$ of the observed enhancement $(+300 \mathrm{ppb}$ on average) over the background (around $100 \mathrm{ppb}$ ), while for EDGARv4.2 the corresponding value is only $53 \%$, indicating strong underestimation of this event. The difference in the calculated $\mathrm{CO}$ using these two inventories is also consistent with the results of Granier et al. (2011), who showed strong discrepancies in the Asian anthropogenic emissions in different inventories.

Figure 6a shows the $\mathrm{CO}$ measurements at cruising altitude during a transatlantic flight between Frankfurt and Denver on 10 March 2002. The dashed blue line represents the residual $\mathrm{CO} C_{\mathrm{UT}}^{\mathrm{R}}$. Observations indicate that the aircraft encountered several polluted air masses with $\mathrm{CO}$ mixing ratios above 110 to $120 \mathrm{ppb}$, which are the seasonal median $\mathrm{CO}$ values in the two regions visited by the aircraft, obtained from the IAGOS database (see Gressent et al., 2014). Three pollution plumes are measured: 

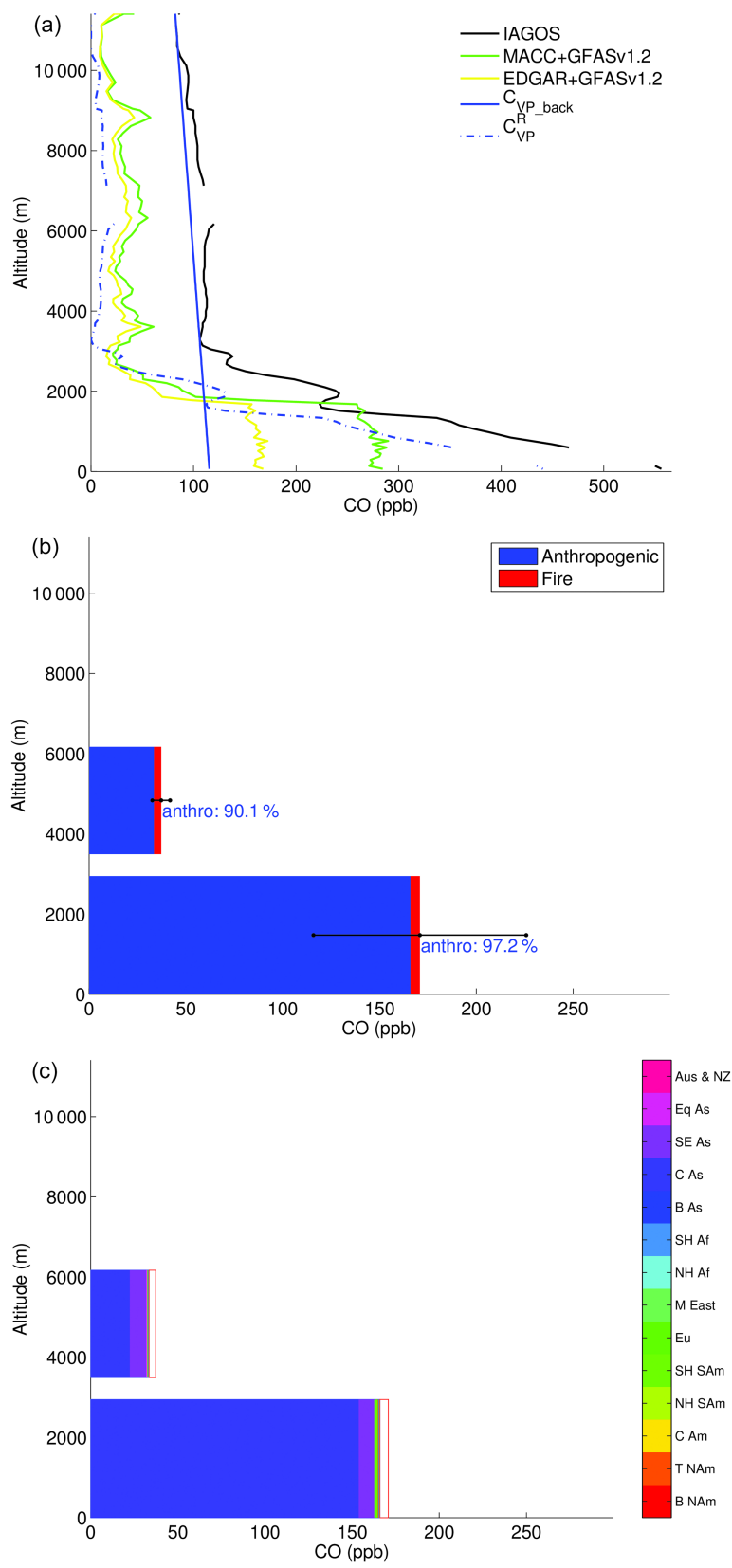

Figure 5. (a) Carbon monoxide profiles over Hong Kong during a MOZAIC-IAGOS flight landing on 22 October 2005. The black line indicates the observed $\mathrm{CO}$ profile while the blue line indicates the $\mathrm{CO}$ background deduced from the observations. Green and yellow lines indicate the simulated $\mathrm{CO}$ contributions using, respectively, MACCity and EDGARv4.2 for anthropogenic emissions and using GFAS v1.2 for biomass burning emissions. Simulated CO is separated into (b) source contribution (anthropogenic in blue, fires in red, standard deviation in black) and (c) regional anthropogenic origins (14 regions defined for global emission inventory, http://www.globalfiredata.org/data.html, see Fig. S1 in the Supplement; unshaded red square is for fire contribution), using MACCity and GFAS v1.2.
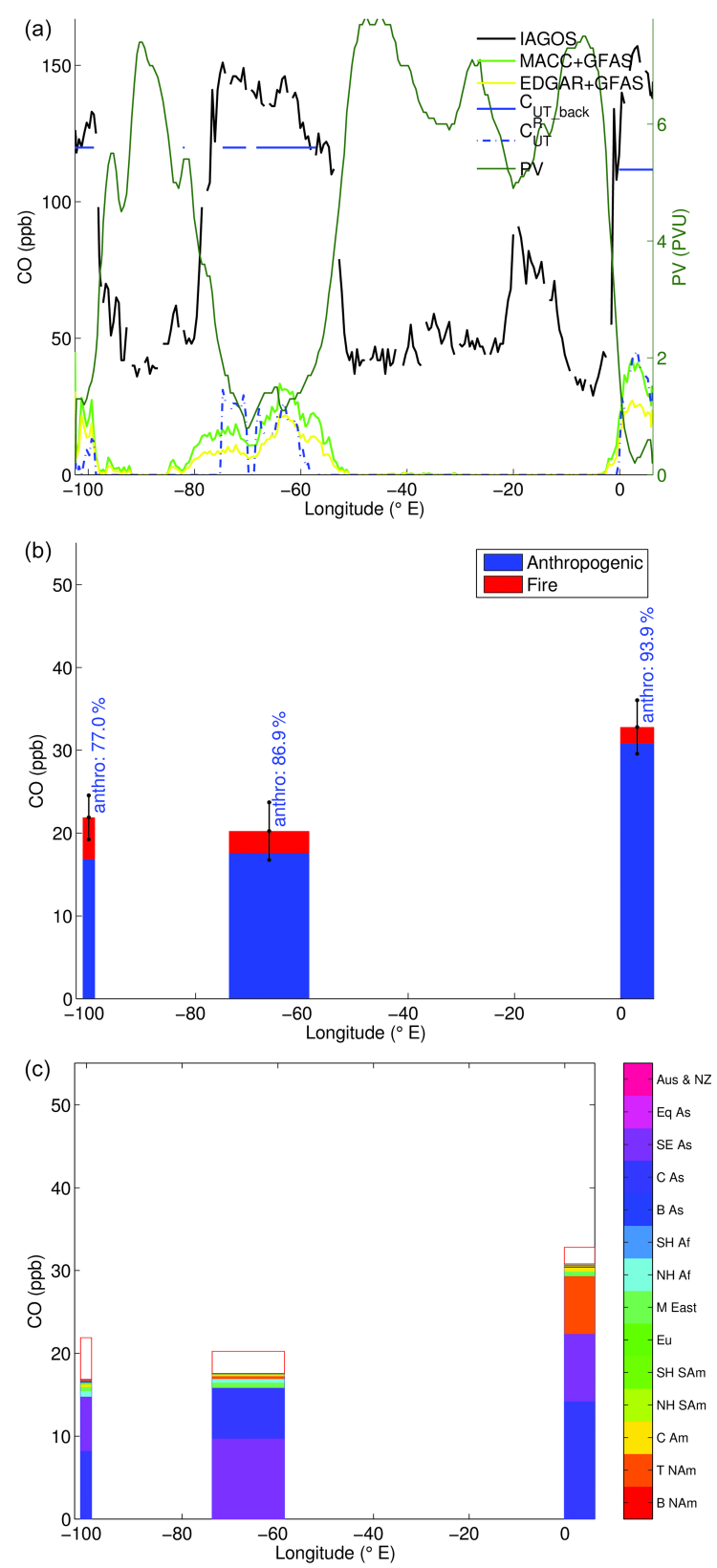

Figure 6. (a) Carbon monoxide zonal profile during the 10 March 2002 MOZAIC-IAGOS flight from Frankfurt to Denver. The black line indicates the observed $\mathrm{CO}$ while the blue line indicates $\mathrm{CO}$ seasonal background in the UT deduced from the IAGOS data set. Light green and yellow lines indicate the simulated contributions using, respectively, MACCity and EDGARv4.2 for anthropogenic emissions and GFAS v1.0 for biomass burning emissions. Dark green represents potential vorticity (PVU) from ECMWF analyses. Simulated CO is separated into (b) source contribution (anthropogenic in blue, fires in red, standard deviation in black) and (c) regional anthropogenic origins (14 regions defined for global emission inventory, http://www.globalfiredata.org/data.html, see Fig. S1; unshaded red square is for fire contribution), using MACCity and GFAS v1.0. 
- plume 1 around $100^{\circ} \mathrm{W}$ (around $+10 \mathrm{ppb}$ of $\mathrm{CO}$ enhancement on average);

- plume 2 between 80 and $50^{\circ} \mathrm{W}(+30 \mathrm{ppb}$ of $\mathrm{CO}$ enhancement on average);

- plume 3 between 0 and $10^{\circ} \mathrm{E}$ ( $+40 \mathrm{ppb}$ of $\mathrm{CO}$ enhancement on average).

These polluted air masses are surrounded by stratospheric air masses with CO values lower than 80-90 ppb. As polluted air masses were sampled at an altitude of around $10 \mathrm{~km}$, they are expected to be due to long-range transport of pollutants.

The calculated CO is shown in Fig. 6a using MACCity (green line), EDGARv4.2 (yellow line) for anthropogenic emissions and GFAS v1.0 for biomass burning emissions. SOFT-IO estimates that these plumes are mostly anthropogenic (representing 77 to $93 \%$ of the total simulated CO, Fig. 6b). Pollution mostly originates from central and Southeast Asia, with strong contribution from North America (Fig. 6c) for plume 3.

SOFT-IO correctly locates the three observed polluted air masses with the two anthropogenic inventories. $\mathrm{CO}$ is also correctly calculated using MACCity, with almost the same mixing ratios on average as the observed enhancements in the three plumes. Using EDGARv4.2, only two-thirds of the observed $\mathrm{CO}$ enhancements intensity is reproduced, except for plume no. 1 with better intensity results. We have already seen in the previous case study that emissions in Asia may be underestimated, especially in the EDGARv4.2 inventory.

Similar comparisons were performed in the four case studies selected to estimate and validate the anthropogenic emission inventories coupled with the FLEXPART model. Results are summarized in Table 3. For three of the cases, SOFTIO simulations showed a better agreement with observations when using MACCity than when using EDGARv4.2. In the fourth case both inventories performed equally well. One reason for the better performance of MACCity is the fact that it provides monthly information (Table 2).

\subsection{Biomass burning emission inventories}

In order to evaluate and choose biomass burning emission inventories, we have selected 11 case studies with fire-induced plumes (Table 1). Seven of them focused on North American biomass burning plumes observed in the free troposphere above Europe (flights on 30 June, 22 and 23 July 2004) and in the upper troposphere-lower stratosphere above the North Atlantic (29 June 2004) (e.g., Elguindi et al., 2010; Cammas et al., 2009). Two are related to the fires over western Europe during the 2003 heat wave (Tressol et al., 2008). The two last ones, on 30 and 31 July 2008, focused on biomass burning plumes observed in the Intertropical Convergence Zone (ITCZ) above Africa as described in a previous study (Sauvage et al., 2007a).

The three data sets selected to represent biomass burning emissions are based on different approaches: GFAS v1.2
(Kaiser et al., 2012) and GFED 4 (Giglio et al., 2013) emissions are calculated daily. GFAS v1.2 presents higher spatial resolution. The ICARTT campaign inventory (Turquety et al., 2007) was specifically designed for North American fires during the summer of 2004 with additional input from local forest services.

Figure 7a illustrates the calculated $\mathrm{CO}$ contributions for the different fire emission inventories for one of the case studies, on 22 July 2004 above Paris. The observations (black line) show high levels of $\mathrm{CO}$ in an air mass in the free troposphere between 3 and $6 \mathrm{~km}$, with mixing ratios $140 \mathrm{ppb}$ above the background (blue line) deduced from measurements. This pollution was attributed to long-range transport of biomass burning emission in North America by Elguindi et al. (2010). Outside of the plume, the CO concentration decreases with altitude, from around $150 \mathrm{ppb}$ near the ground to $100 \mathrm{ppb}$ background in the upper free troposphere. This last value corresponds to the median $\mathrm{CO}$ seasonal value deduced from the IAGOS database (Gressent at al., 2014). $\mathrm{CO}$ is not considered as an anomaly near the ground to be $C_{\mathrm{UT}}^{\mathrm{R}}<C_{\mathrm{UT} \text { _season }}^{\mathrm{R}}$ (Q3).

SOFT-IO simulations were performed for this case using MACCity to represent anthropogenic emissions and GFAS v1.2 (green line), GFED 4 (yellow line) or the ICARTT campaign inventory (red line). Fire vertical injection is realized using the MIXED approach for the three biomass burning inventories, in order to only evaluate the impact of choosing different emission inventories. In the three simulations, contributions show two peaks, one near the ground that is half due to local anthropogenic emissions and half due to contributions from North American biomass burning and thus not considered in this discussion.

The second, more intense peak, simulated in the free troposphere where the enhanced $\mathrm{CO}$ air masses were sampled, is mostly caused by biomass burning emissions $(87 \%$ of the total calculated CO; Fig. 7b), originating from North America (99\% of the total enhanced CO). When calculated using the ICARTT campaign inventory, the simulated $\mathrm{CO}$ enhancement reaches over $150 \mathrm{ppb}$, which is $10 \mathrm{ppb}$ higher than the observed mixing ratio above the background ( $+140 \mathrm{ppb})$, but only for the upper part of the plume.

When using global inventories, the simulated contribution peak reaches $70 \mathrm{ppb}$ using GFAS v1.2 and $100 \mathrm{ppb}$ using GFED4, which appears to underestimate the measured enhancement $(+140 \mathrm{ppb})$ by up to 50 to $70 \%$, respectively. This comparison demonstrates the large uncertainty in simulated $\mathrm{CO}$ caused by the emission inventories, both in the case of biomass burning or anthropogenic emissions. For that reason we aim to provide simulations with different global and regional inventories in for the IAGOS data set.

As the ICARTT campaign inventory was created using local observations in addition to satellite products, the large difference in the simulated CO compared to the other inventories may in part be due to different quantification of the total area burned (for GFED, GFAS using the FRP as con- 
Table 3. Summary of the averaged observed and simulated anomaly and corresponding averaged standard deviation (SD) (in ppb) determined for representing anthropogenic emissions for different case studies (using GFAS v1.2 for biomass burning emissions). Altitude of the anomaly is indicated: planetary boundary layer (PBL) and upper troposphere (UT).

\begin{tabular}{llllllll}
\hline Flight & $\begin{array}{l}\text { IAGOS } \\
\text { anomaly }\end{array}$ & $\begin{array}{l}\text { IAGOS SD } \\
\text { anomaly }\end{array}$ & $\begin{array}{l}\text { MACCity } \\
\text { SD }\end{array}$ & $\begin{array}{l}\text { MACCity } \\
\text { anomaly }\end{array}$ & $\begin{array}{l}\text { EDGAR } \\
\text { SD }\end{array}$ & $\begin{array}{l}\text { EDGAR } \\
\text { altitude }\end{array}$ & Anomaly \\
\hline 10 March 2002 Frankfurt-Denver & 16.8 & 8.7 & 20.2 & 6.9 & 12.8 & 5.1 & UT \\
27 November 2002 Dallas-Frankfurt & 28.0 & 8.6 & 20.0 & 8.0 & 16.4 & 7.4 & UT \\
19 July 2005 Munich-Hong Kong & 130.1 & 97.8 & 45.8 & 9.7 & 34.6 & 7.7 & PBL \\
22 October 2005 Munich-Hong Kong & 157.9 & 105.1 & 170.7 & 109.8 & 103.9 & 62.0 & PBL \\
\hline
\end{tabular}

straint). Turquety et al. (2007) also discussed the importance of peat land burning during that summer. They estimated that they contributed more than a third of total $\mathrm{CO}$ emissions (11 Tg of the $30 \mathrm{Tg}$ emitted during summer 2004).

Figure 8a shows $\mathrm{CO}$ mixing ratios as a function of latitude for a flight from Windhoek (Namibia) to Frankfurt (Germany) in July 2008. Observations indicate that the aircraft flew through polluted air masses around the Equator $\left(10^{\circ} \mathrm{S}\right.$ to $10^{\circ} \mathrm{N}$ ), with $+100(+125)$ ppb of $\mathrm{CO}$ on average (at the most) above the $90 \mathrm{ppb}$ background deduced from seasonal IAGOS mixing ratios over this region. Such CO enhancements have been attributed to regional fires injected through ITCZ convection (Sauvage et al., 2007b).

The SOFT-IO simulations (colored lines in Fig. 8a) link these air masses mostly to recent biomass burning (responsible for $68 \%$ of the total simulated CO, Fig. 8b) in South Africa (Fig. 8c). The calculated $\mathrm{CO}$ shows similar features both with GFED4 (yellow line) and GFAS v1.2 (green line). The simulation also captures well the intensity variations of the different peaks: maximum values around the Equator, lower ones south and north of the Equator. The most intense simulated $\mathrm{CO}$ enhancement around the Equator fits the observed $\mathrm{CO}$ enhancement of +125 ppb better when using GFED4 (90 ppb) than when using GFAS v1.2 (75 ppb). However, the comparison also reveals an underestimation of the $\mathrm{CO}$ anomaly's amplitude by around 10 to $25 \mathrm{ppb}$ on average by SOFT-IO. The model is thus only able to reproduce $75 \%$ to $90 \%$ of the peak concentrations on average. Stroppiana et al. (2010) indeed showed that there are strong uncertainties in the fire emission inventories over Africa (164 to $367 \mathrm{Tg}$ $\mathrm{CO}$ per year).

\section{Statistical evaluation of the modeled CO enhancements in pollution plumes}

In this section, we present a statistical validation of the SOFT-IO calculations based on the entire IAGOS CO database (2003-2013). The ability of SOFT-IO in simulating $\mathrm{CO}$ anomalies is evaluated compared to in situ measurements in terms of

- spatial and temporal frequency of the plumes and
- mixing ratio enhancements in the plumes.

To achieve this, SOFT-IO performances are investigated over different periods of IAGOS measurements depending on the emission inventory used. Three of the four global inventories selected previously (MACCity, GFAS v1.2, GFED4) are available between 2003 and 2013. EDGAR v4.2 ends in 2008. In the following sections (Sect. 5.1 and 5.2), we discuss in detail the results obtained with MACCity and GFAS v1.2 between 2003 and 2013. Other emission inventory combinations are discussed in Sect. 5.3 when investigating SOFT-IO sensitivity to input parameters.

\subsection{Detection frequency of the observed plumes with SOFT-IO}

The ability of SOFT-IO to reproduce CO enhancements was investigated using $\mathrm{CO}$ plumes obtained applying the methodology described in Sect. 3.4 on all flights of the IAGOS database between 2003 and 2013. The frequency of simulated plumes that coincide with the observed $C^{\mathrm{A}}$ anomalies is then calculated. Simulated plumes are considered when matching in time and space the observed plumes, while modeled $\mathrm{CO}$ is on average higher than $5 \mathrm{ppb}$ within the plume. Note that at this stage we do not consider the intensity of the plumes.

The resulting detection rates are presented in Fig. 9 for 8 of the 11 regions shown in Fig. 4. Statistics are presented separately for three altitude levels: lower troposphere (LT) at $0-2 \mathrm{~km}$, middle troposphere (MT) at $2-8 \mathrm{~km}$ and UT > $8 \mathrm{~km}$. Figure 9 shows that SOFT-IO performance in detecting plumes is very good and not strongly altitude or region dependent. In the three layers (LT, MT and UT), detection rates are higher than $95 \%$ and even close to $100 \%$ in the LT, where $\mathrm{CO}$ anomalies are often related to short-range transport. Detection frequency slightly decreases in the MT and the UT, where $\mathrm{CO}$ modeling accuracy suffers from larger errors in vertical and horizontal transport. In contrast, $\mathrm{CO}$ anomalies in the LT are most often related to short-range transport of local pollution, which is well represented in SOFT-IO. For four regions we found worse results - South American MT and UT, African MT and northern Asian UT - but with high detection frequency ( 82 to $85 \%$ ). Note that only relatively 

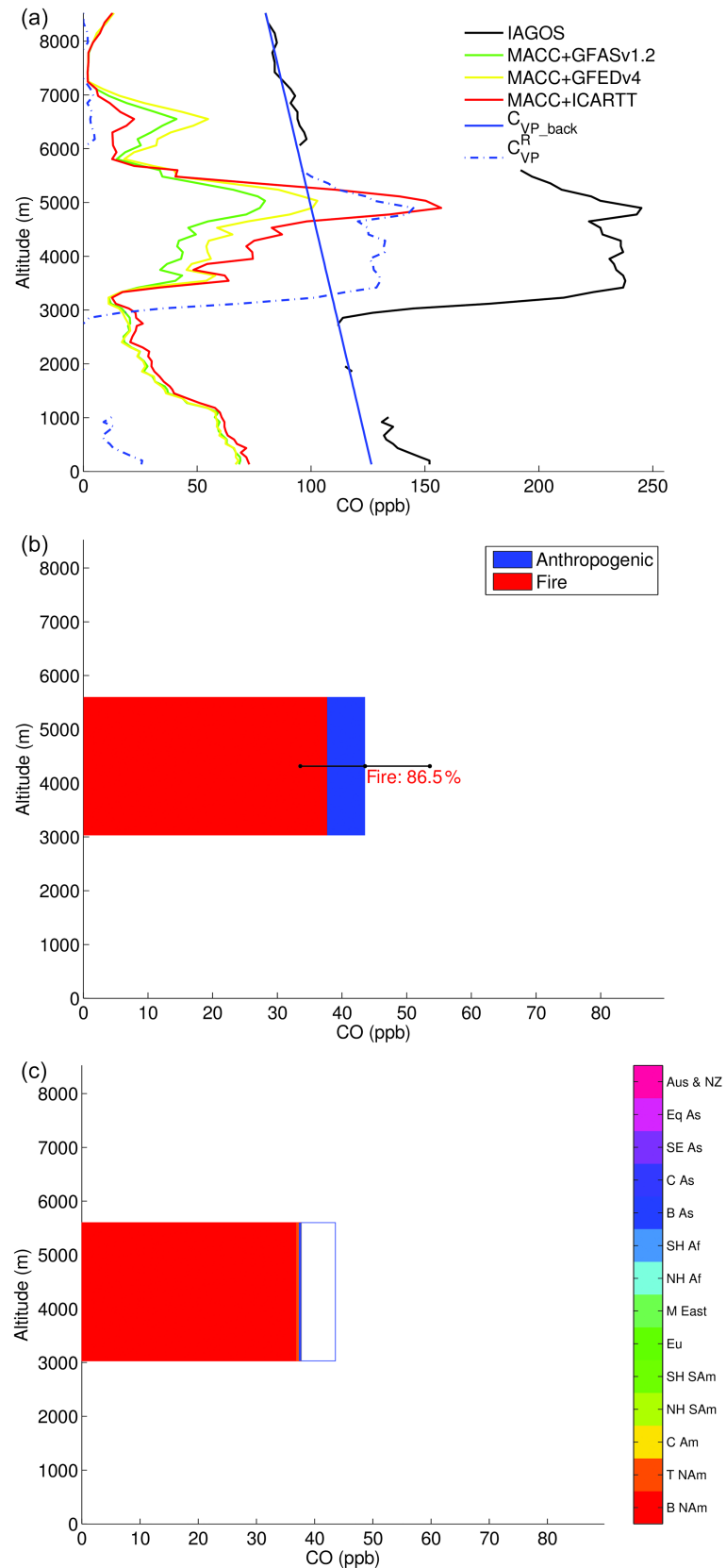

Figure 7. (a) Carbon monoxide profiles over Paris during a MOZAIC-IAGOS flight landing on 22 July 2004. The black line indicates the observed $\mathrm{CO}$ profile and the blue line indicates $\mathrm{CO}$ background deduced from the observations. Green, yellow and red lines indicate the simulated contributions using, respectively, GFAS v1.2, GFED4 and ICARTT for biomass burning emissions, with MACCity for anthropogenic emissions. Simulated CO is separated into (b) source contribution (anthropogenic in blue, fires in red, standard deviation in black) and (c) regional biomass burning origins (14 regions defined for global emission inventory, http://www. globalfiredata.org/data.html see Fig. S1; unshaded blue square is for anthropogenic contribution), using MACCity and GFAS v1.2.
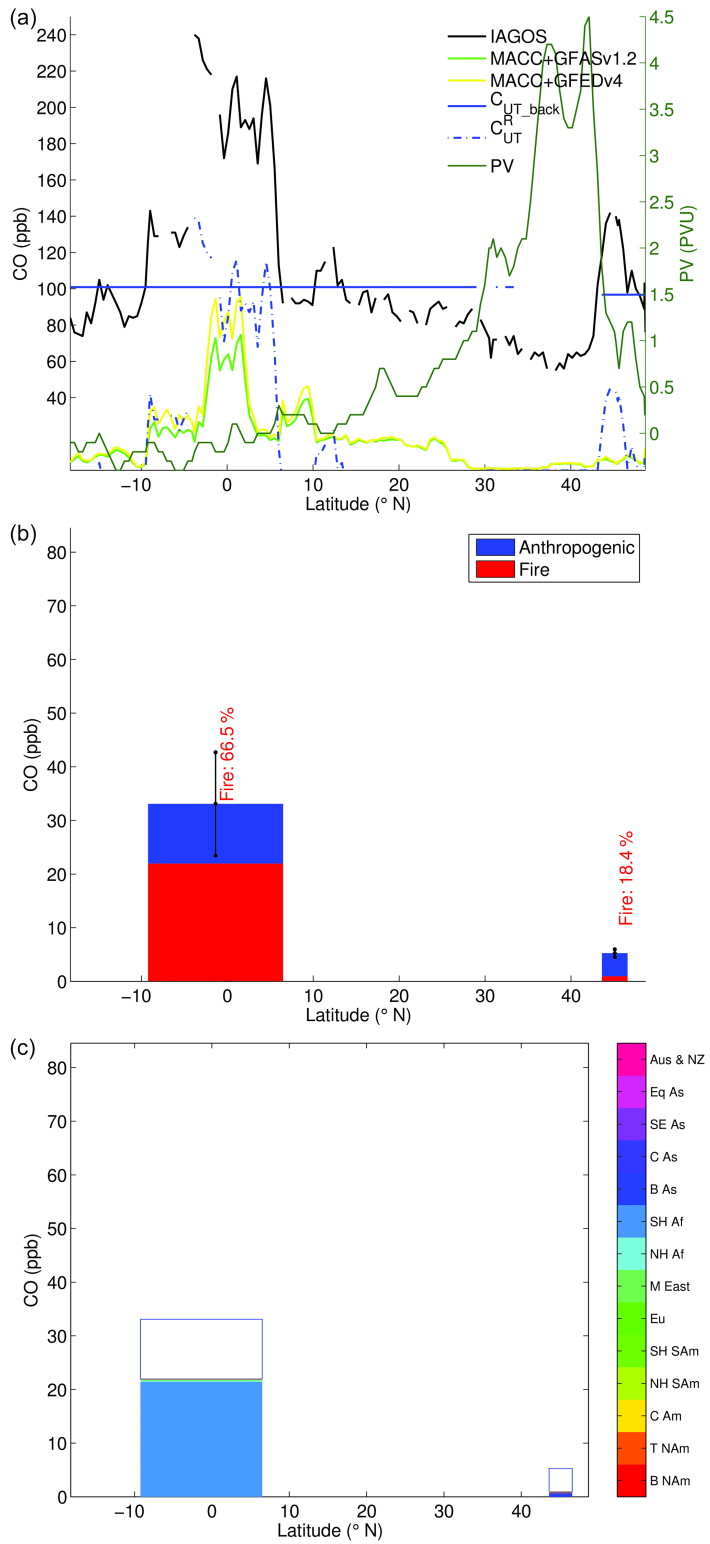

Figure 8. (a) Carbon monoxide as a function of latitude during the 30 July 2008 MOZAIC-IAGOS flight from Windhoek to Frankfurt. The black line indicates the observed $\mathrm{CO}$, the blue line indicates the $\mathrm{CO}$ seasonal background deduced from the IAGOS data set and the dash-dotted line the residual $\mathrm{CO}$ mixing ratio. Light green and yellow lines indicate the simulated contributions using MACCity for anthropogenic emissions and, respectively, GFAS v1.2 and GFED4 for biomass burning emissions. Dark green represents potential vorticity (PVU) from ECMWF analyses. Simulated CO is separated into (b) source contribution (anthropogenic in blue, fires in red, standard deviation in black) and (c) regional biomass burning origins (14 regions defined for global emission inventory, http://www.globalfiredata.org/data.html, see Fig. S1; unshaded blue square is for anthropogenic contribution), using MACCity and GFAS v1.2. 


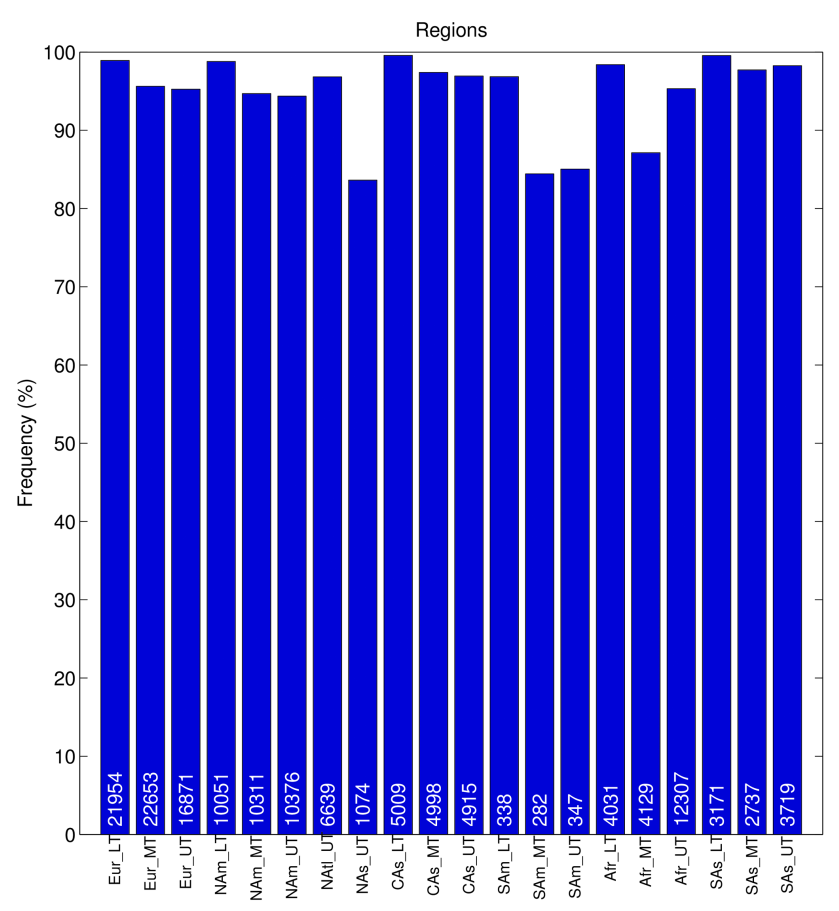

Figure 9. Frequency of plume detection in different regions, altitudes and seasons using the MACCity and GFAS v1.2 emission inventories during the 2003-2013 period. Biomass burning vertical injection uses APT methodology. Altitude levels stand for LT $(0-2 \mathrm{~km})$, MT $(2-8 \mathrm{~km})$ and UT ( $8 \mathrm{~km}$-tropopause). The number of plumes observed in each case is displayed in each box.

few plumes (313 to 3761) were sampled by the IAGOS aircraft fleet in these regions.

\subsection{Intensity of the simulated plumes}

The second objective of SOFT-IO is to accurately simulate the intensity of the observed $\mathrm{CO}$ anomalies. Figure 10a displays the bias between the means of the observed and modeled plumes for the regions sampled by IAGOS and in the three vertical layers (LT, MT and UT), and the bias of the standard deviations in black. As explained above this bias is calculated for the 2003-2013 period and using both anthropogenic emission from MACCity and biomass burning emissions from GFAS v1.2 and the APT plume detection methodology described in Sect. 3.4.

The most documented regions presenting $\mathrm{CO}$ polluted plumes (Europe, North America, Africa, North Atlantic UT, central Asian MT and UT, South America, south Asian UT) present low biases (lower than $\pm 5 \mathrm{ppb}$; up to $\pm 10 \mathrm{ppb}$ for central Asian MT and South American UT) and low bias of the standard deviations ( \pm 10 to $\pm 50 \mathrm{ppb}$ ), which demonstrates a high skill of SOFT-IO.

Over several other regions with less frequent IAGOS flights, however, biases are higher, around $\pm 10-15 \mathrm{ppb}$ for African UT and south Asian MT and around $\pm 25-50 \mathrm{ppb}$ for central Asian LT, south Asian LT and north Asian UT. Except for the last region, the highest biases are found in the Asian LT, suggesting misrepresentation of local emissions. This is supported by the highest biases of the standard deviations (from \pm 60 to $\pm 160 \mathrm{ppb}$ for Asian regions). Indeed there is a rapid increase of emissions in this large area (Tanimoto et al., 2009) associated with high discrepancies between different emission inventories (Wang et al., 2013; Stein et al., 2014) and underestimated emissions (Zhang et a., 2015).

It is important to note that the biases remain of the same order $( \pm 10-15 \mathrm{ppb})$ when comparing the first $(\mathrm{Q} 1)$, second (Q2) and third (Q3) quartiles of the CO anomalies observed and modeled within most of the regions (Fig. 10b). This confirms the good capacity of the SOFT-IO software in reproducing the $\mathrm{CO}$ mixing ratios anomaly in most of the observed pollution plumes.

Differences become much larger when considering outlier values of $\mathrm{CO}$ anomalies (lower and upper whiskers, $\pm 2.7 \sigma$ or $99.3 \%$; Fig. 10b), i.e., exceptional events of very low and very high $\mathrm{CO}$ enhancements (accounting for $1.4 \%$ of the $\mathrm{CO}$ plumes), with biases from \pm 10 to $\pm 50 \mathrm{ppb}$ for most of the regions. Higher discrepancies are found in the lower and the upper troposphere in two specific regions (north Asian UT and south Asian LT) for these extreme CO anomalies. North Asian UT discrepancies varies from -100 to $+200 \mathrm{ppb}$ and from -50 to $+100 \mathrm{ppb}$ for south Asian LT. Note that north Asian UT and south Asian LT present extreme pollution events related to pyro-convection (Nédélec et al., 2005) for the first region and to strong anthropogenic surface emissions (Zhang et al., 2012) for the second one. This may suggest that the model fails to correctly reproduce the transport for some specific but rare events of pyro-convection or that these emission inventories are under estimated for such specific events.

When looking at the origin of the different $\mathrm{CO}$ anomalies (Fig. 10c), most of them are dominated by anthropogenic emissions, which account for more than $70 \%$ of the contributions on average, except for South America and Africa, which are strongly influenced by biomass burning (Sauvage et al., 2005, 2007c; Yamasoe et al., 2014). Discussing origins of the $\mathrm{CO}$ anomalies in detail is out of the scope of this study but does give some sense of the model performance here. It is interesting to note that two of the three regions most influenced by anthropogenic emissions, south Asian LT and central Asian LT, with more than $90 \%$ of the enhanced CO coming from anthropogenic emissions, are the highest biased regions compared to observations. This is not the case for $\mathrm{Eu}-$ ropean LT, for example, which also has a high anthropogenic influence. As stated before, anthropogenic emissions in Asia are more uncertain than elsewhere (Stein et al., 2014).

In order to go a step further in the evaluation of SOFT-IO in reproducing $\mathrm{CO}$ anomalies mixing ratios, Fig. 11 displays the monthly mean time series of the observed (black line) and calculated (blue line) $\mathrm{CO}$ anomalies in three vertical layers (LT, MT and UT) and the standard deviation of the observations (gray) and calculations (light blue). This graph pro- 

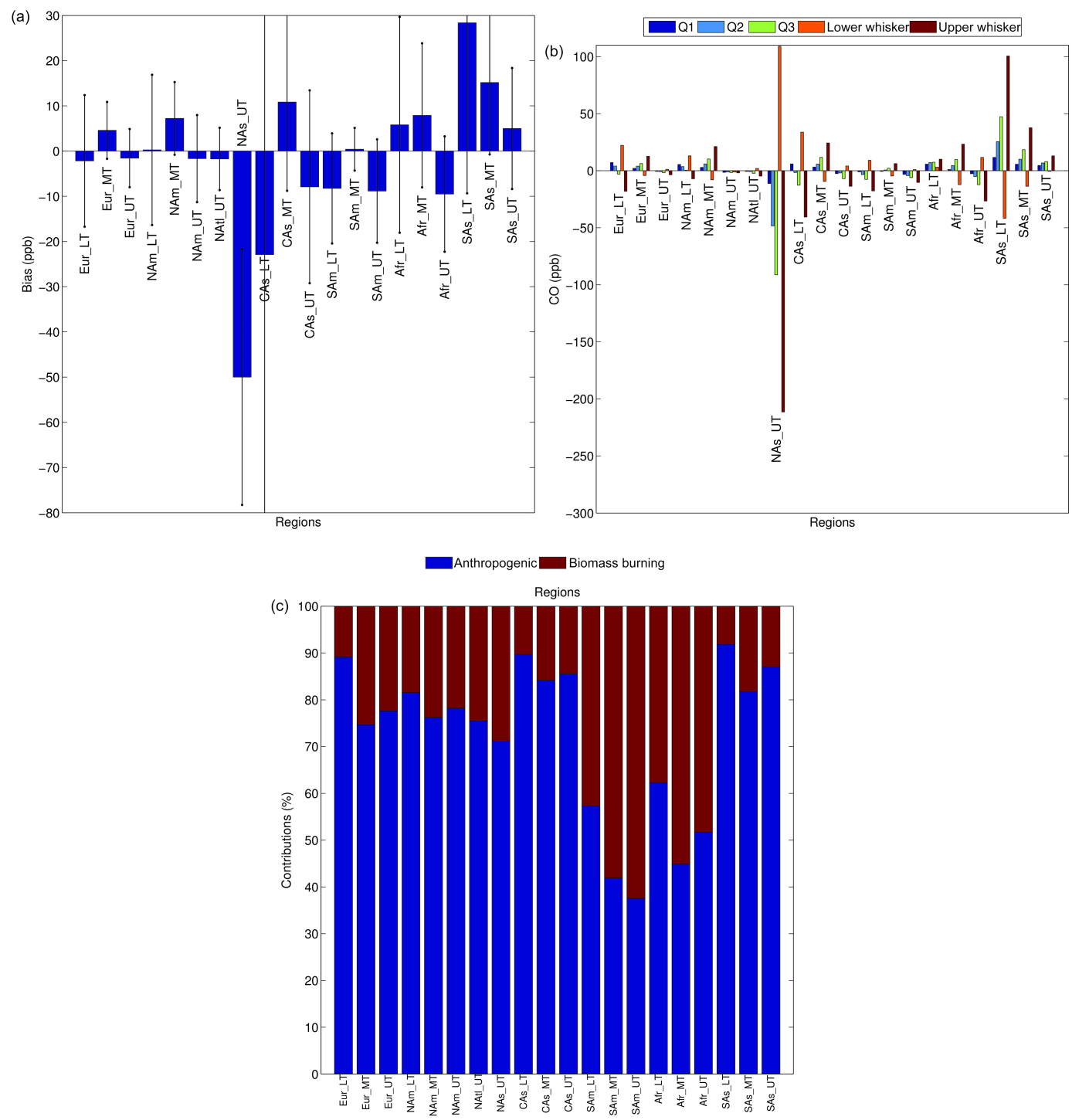

Figure 10. (a) Mean bias (blue) and mean standard deviation bias (black) between the modeled and observed CO anomalies. (b) Percentiles of the modeled $\mathrm{CO}$ anomalies bias with respect to observations. (c) Relative contribution from anthropogenic and biomass burning sources to the modeled CO. The three graphs are for the main sampled regions (Europe, North America, North Atlantic, northern Asia, central Asia, South America, Africa, southern Asia) and in three layers (LT, MT, UT), using MACCity and GFAS v1.2 for the 2003-2013 period. Biomass burning vertical injection uses APT methodology.

vides higher temporal resolution of the anomalies. $\mathrm{CO}$ polluted plumes are displayed here using MACCity and GFAS v1.2 over the 2003-2013 periods and for the two regions with the largest number of observed $\mathrm{CO}$ anomalies, Europe and North America.

It is worth noting the good ability of SOFT-IO in quantitatively reproducing the $\mathrm{CO}$ enhancements observed by IAGOS. This is especially noticeable in the LT and UT, with similar CO mixing ratios observed and modeled during the entire period and within the standard deviation of the measurements. Standard deviation of the observations is higher in LT, where there are fewer measurements than in the UT.
However, the amplitude of the seasonal cycle of $\mathrm{CO}$ maxima is highly underestimated $(-100 \%)$ after January 2009 in the European LT, where anthropogenic sources are predominant with more than $90 \%$ influence (Fig. 10c). This suggests misrepresentation of anthropogenic emissions in Europe after the year 2009. Indeed Stein et al. (2014) suggested the lower near-surface $\mathrm{CO}$ bias was found in Europe in relation to possible underestimation of traffic emissions in the inventories.

In the middle troposphere $(2-8 \mathrm{~km})$, the $\mathrm{CO}$ plumes are systematically overestimated by SOFT-IO by 50 to $100 \%$ compared to the observations, with larger standard deviation 

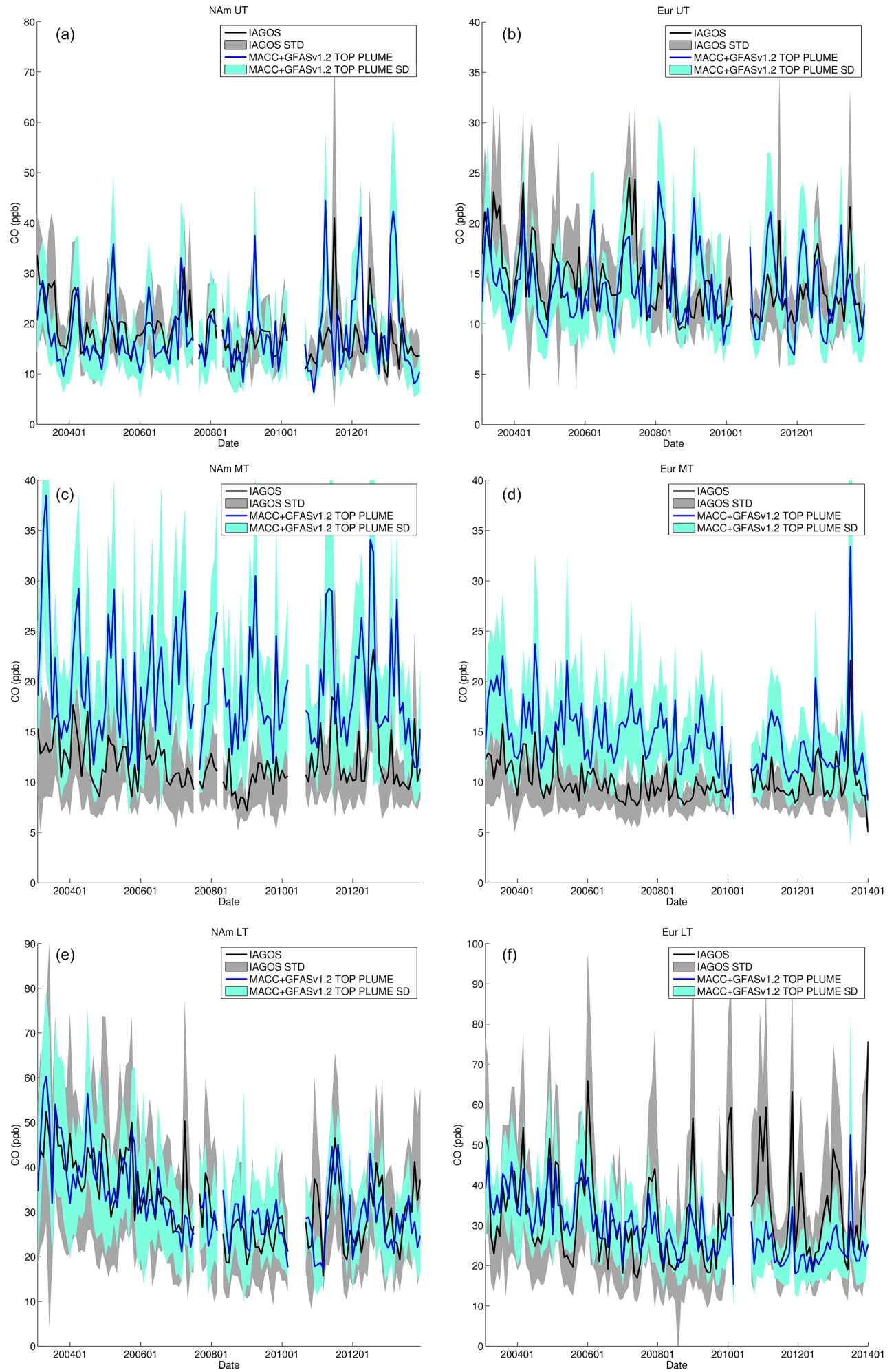

Figure 11. Times series (monthly means between 2003 and 2013) of the observed (black) and simulated (blue) plumes of CO enhancements for the two most documented regions (North America and Europe) in the LT (e, f), MT (c, d) and UT (a, b), using MACCity and GFAS v1.2. Standard deviations are in gray (observations) and light blue (SOFT-IO). Biomass burning vertical injection uses APT methodology. 
and higher overestimation over North America. This might be related to different reasons: (1) the chosen methodology of the $\mathrm{CO}$ plume enhancements detection for those altitudes (described in Sect. 3.4), which may lead to a large number of plumes with small CO enhancements, which are difficult to simulate. This could be due to the difficulty of defining a realistic $\mathrm{CO}$ background in the middle troposphere. (2) The source-receptor transport may be more difficult to simulate between 2 and $8 \mathrm{~km}$ than in the LT, where receptors are close to sources, or in the UT, where most of the plumes are related to convection detrainment better represented in the models than MT detrainment, which might be less intense. (3) The frequency of the IAGOS observations is lower in the LT and MT than in the UT.

Higher overestimation over North American MT than European MT could be related to the lower frequency of measurements in North America. Moreover, overestimation is greater during summer when North American MT is closer to summer sources such as boreal fires, while European MT is related to $\mathrm{CO}$ air masses more diluted with background air during transatlantic transport.

Correlation coefficients between simulated and observed plumes are highest in the LT (0.56 to 0.79$)$ and lower ( 0.30 to 0.46 ) in the MT and in the UT, suggesting some difficulties for the model in lifting up pollution from the surface to the UT.

\subsection{Sensitivity of SOFT-IO to input parameters}

Different factors influence the ability of SOFT-IO to correctly reproduce $\mathrm{CO}$ pollution plumes. Among them, transport parameterizations (related to convection, turbulence, etc.) are not evaluated in this study as they are inherent to the FLEXPART model. In this section, the model sensitivity to the chosen emission inventory is evaluated. For this, a set of sensitivity studies is performed to investigate different configurations of the emission inventories.

- Type of inventory: MACCity or EDGAR for anthropogenic emissions; GFED4, GFAS v1.2 or ICARTT for biomass burning.

- Biomass burning injection heights: DENTENER, MIXED or APT approach (detailed in Sect. 3.3).

SOFT-IO performances are then investigated using Taylor diagrams (Taylor et al., 2001). The methodology (choice of regions, vertical layers, sampling periods) is similar to the one used to analyze the ability of the model to correctly reproduce the frequency and the intensity of the $\mathrm{CO}$ plumes with MACCity and GFAS (Sect. 5.1 and 5.2).

\subsubsection{Anthropogenic emission inventories}

Sensitivity of SOFT-IO to anthropogenic emissions is investigated between 2002 and 2008, using GFAS with MACCity or EDGARv4.2. Figure 12a presents a Taylor diagram for the
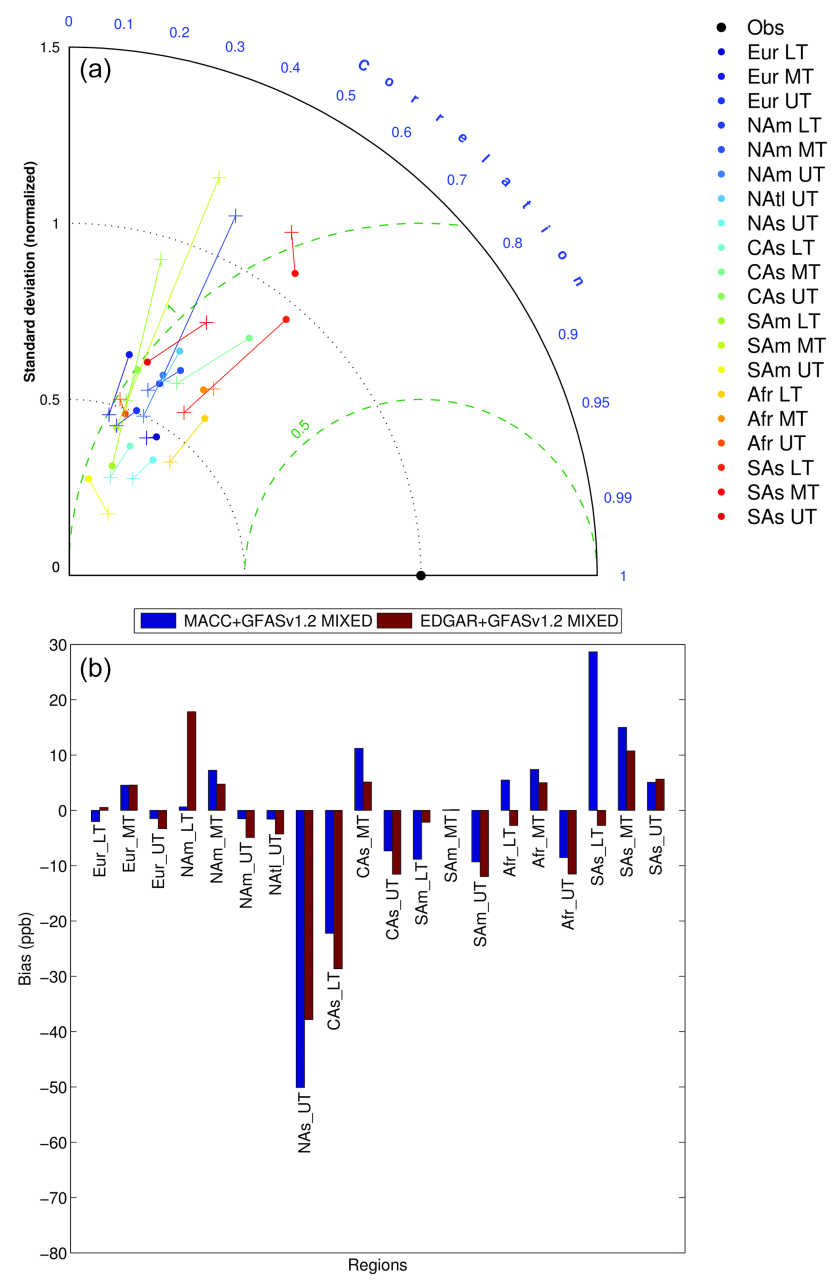

Figure 12. Comparison of the SOFT-IO anthropogenic emission influence between 2002 and 2008. (a) Taylor diagrams are obtained for the different regions and in the three vertical layers (LT, MT and UT) using MACCity (dots) and EDGARv4.2 (crosses) with GFAS (lines represent connections between the two inventories). (b) Mean biases between the modeled (blue for MACCity + GFAS; brown for EDGARv4.2 + GFAS) and observed CO anomalies. The MIXED methodology is used for fire vertical injection.

two configurations (dots for MACCity, crosses for EDGAR) for the regions and for the vertical layers described previously (Sect. 5.1 and 5.2), while Fig. 12b represents the mean bias between each model configuration and the IAGOS observations.

As already seen in Sect. 4.1 for the case studies chosen to investigate anthropogenic emissions, slightly better results seem to be obtained with MACCity. The Taylor diagram shows for most of the regions higher correlations and lower biases in this case. These results are not surprising, as MACCity (Lamarque et al., 2010; Grenier et al., 2011) is a more recent inventory compared to EDGARv4.2 (JanssensMaenhout et al., 2010) and expected to better represent anthropogenic emissions. However, as stated in Lamarque et 
al. (2010), both inventories share many aspects (for example over Latin and South America), and the differences between the two inventories are very low most of the time, as global emission inventories tend to be quite similar.

Regionally, however, results with EDGARv4.2 can be better by almost $50 \%$, such as over south Asian LT and MT and central Asian LT and MT. This supports our choice of maintaining several different inventories in SOFT-IO.

\subsubsection{Biomass burning emissions}

We first investigate the sensitivity of SOFT-IO to the type of biomass burning inventory, using MACCity with GFAS v1.2 or GFED 4 (2003-2013) and the same MIXED methodology for vertical injection of emissions (Fig. 2). As for anthropogenic emissions, Fig. 13 represents the Taylor diagram and averaged biases for the different configurations.

Performances (correlations, standard deviations and biases) are very similar for both biomass burning inventories, with smaller differences compared to anthropogenic inventories. Even for regions dominated by biomass burning such as Africa or South America as depicted previously (Fig. 11c), the sensitivity of the SOFT-IO performance to the type of global fire inventory is below $5 \mathrm{ppb}$.

Based on case studies, we discussed in Sect. 4.2 the comparison of $\mathrm{CO}$ contributions modeled using regional fire emission inventories. It resulted in a better representation of biomass burning plumes using the specifically designed campaign inventory than using the global inventories (Table 4). However, there is no clear evidence of this result when investigating the model performances during the whole summer 2008. In contrast to Sect. 4.2, it is hard to obtain systematically better results using the ICARTT inventory. While simulations (not shown) give better results for a few specific events of very high CO using ICARTT, similarly good results are obtained when using GFAS v1.2 or GFED4 for most other cases. It is worth noting that IAGOS samples biomass burning plumes far from ICARTT sources, after dispersion and diffusion during transport in the atmosphere. Besides, few boreal fire plumes (which would be better represented using ICARTT) are sampled by the IAGOS program.

Secondly, we investigate the influence of the vertical injection scheme for the biomass burning emissions, using the three methodologies for determining injection heights described in Sect. 3.3. Sensitivity tests (Fig. 13c and d) demonstrate a small influence of the injection scheme on the simulated plumes. The largest influence is found over north Asian UT, where pyro-convection has been highlighted in the IAGOS observations (Nédélec et al., 2005), but with less than $5 \mathrm{ppb}$ difference between the different schemes. More generally, small vertical injection influence is probably due to too few cases where boreal fire emissions are injected outside the PBL by pyro-convection, as shown in the Paugam et al. (2016) study, combined with a too low sampling frequency of boreal fire plumes by IAGOS.

\section{Conclusions}

Analyzing long-term in situ observations of trace gases can be difficult without a priori knowledge of the processes driving their distribution and seasonal or regional variability, like transport and photochemistry. This is particularly the case for the extensive IAGOS database, which provides a large number of aircraft-based in situ observations (more than 51000 flights so far) distributed on a global scale and with no a priori sampling strategy, unlike dedicated field campaigns.

In order to help studying and analyzing such a large data set of in situ observations, we developed a system that allows quantifying the origin of trace gases in terms of both geographical location and source type. The SOFT-IO module (https://doi.org/10.25326/2) (https://doi.org/10.25326/2) (Sauvage et al., 2017a) is based on the FLEXPART particle dispersion model, which is run backward from each trace gas observation, and on different emission inventories (EDGAR v4.2, MACCity, GFED 4, GFAS v1.2) that can be easily changed.

The main advantages of the SOFT-IO module are as follows:

- It is flexible. Source-receptor relationships precalculated with the FLEXPART particle dispersion model can be coupled easily with different emission inventories, allowing each user to select model results based on a range of different available emission inventories.

- The CO calculation is computationally very efficient and can be repeated easily whenever updated emission information becomes available, without running the FLEXPART model again. It can also be extended to a larger number of emission data sets, particularly when new inventories become available or for emission inventories intercomparisons. It can also be extended to other species with similar or longer lifetimes as CO to study other types of pollution sources.

- The high sensitivity of the SOFT-IO CO mixing ratios to source choice for very specific regions and case studies, especially in the LT most of the time driven by local or regional emissions, may also help improve emission inventories estimates through evaluation with a large database such as IAGOS. Indeed, as it is based on a Lagrangian dispersion model, the tool presented here is able to reproduce small-scale variations, which facilitates comparison to in situ observations. It can then be used to validate emission inventories by confronting them to downwind observations of the atmospheric composition, using large databases of in situ observations of recent pollution.

- More generally SOFT-IO can be used in the future for any kind of atmospheric observations (e.g., groundbased measurements, satellite instruments, aircraft campaigns) of passive tracers. 

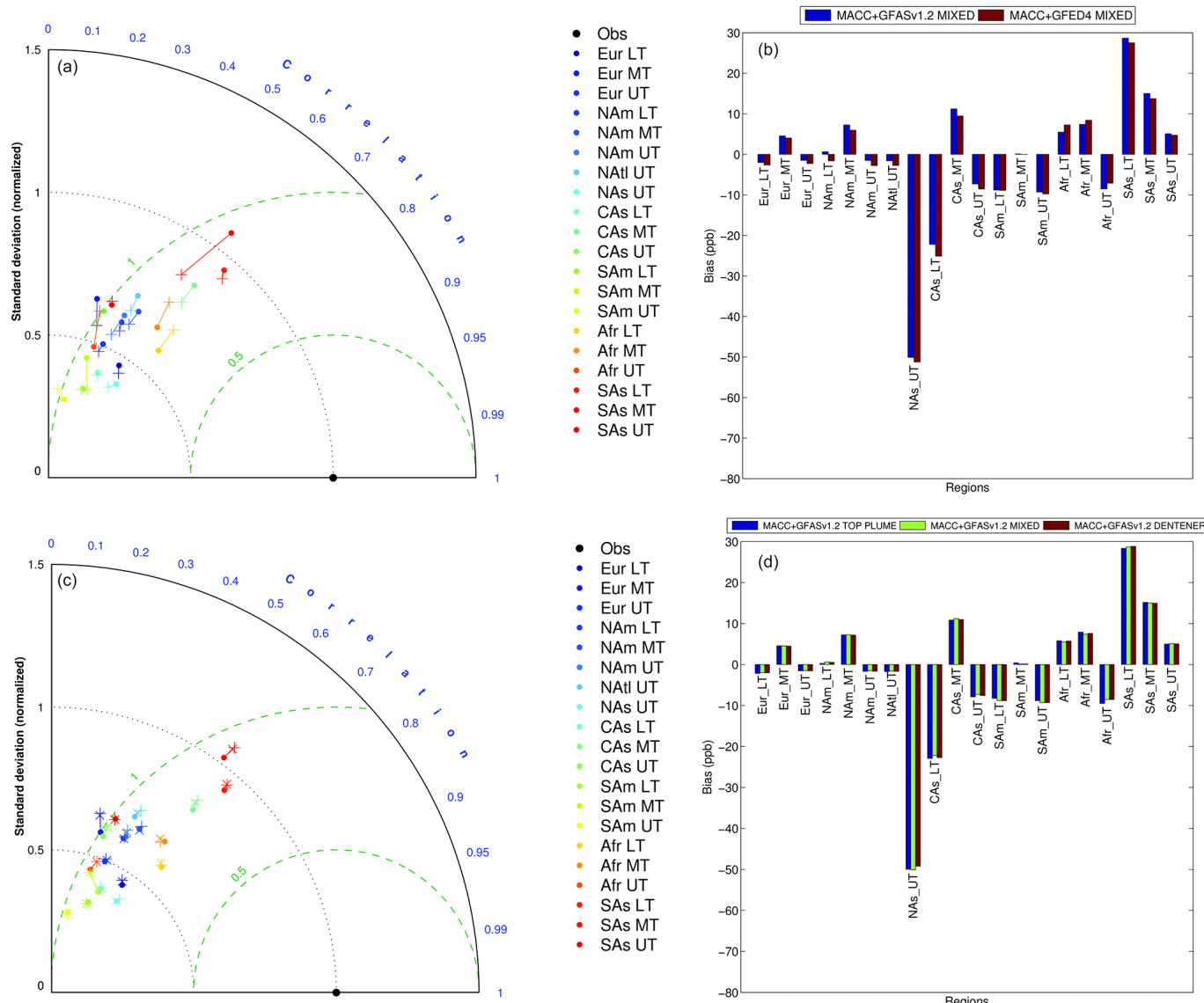

Figure 13. Comparison of the SOFT-IO biomass burning emission influence between 2003 and 2013. Taylor diagrams are obtained for the different regions and in the three vertical layers (LT, MT and UT) using (a) GFAS v1.2 (dots) and GFED4 (crosses) with MACCity and MIXED methodology for both GFAS v1.2 and GFED4 (lines represent connections between the two inventories) and (c) GFAS v1.2 and MACCity with different vertical fire injections methodologies: MIXED (dots), APT (plus) and DENTENER (crosses) (lines represent connections between the two inventories). Mean biases between modeled and observed CO anomalies. Model is using (b) GFAS v1.2 + MACCity (blue), GFED4 + MACCity (brown) and MIXED methodology for both GFAS v1.2 and GFED4. (d) GFAS v1.2 + MACCity and different vertical fire injections methodologies: MIXED (blue); APT (green) and DENTENER (brown).

Table 4. Summary of the averaged observed and simulated anomaly and corresponding averaged standard deviation (SD) (in ppb) determined for representing biomass burning emissions for different case studies (using MACCity for anthropogenic emissions). Altitude of the anomaly is indicated: boundary layer (PBL); middle troposphere (MT); upper troposphere (UT). Note that the ICARTT inventory is only available for summer 2004.

\begin{tabular}{|c|c|c|c|c|c|c|c|c|c|}
\hline Flight & $\begin{array}{l}\text { IAGOS } \\
\text { anomaly }\end{array}$ & $\begin{array}{l}\text { IAGOS } \\
\text { SD }\end{array}$ & $\begin{array}{l}\text { GFAS v1.2 } \\
\text { anomaly }\end{array}$ & $\begin{array}{l}\text { GFAS } \\
\text { v1.2 SD }\end{array}$ & $\begin{array}{l}\text { GFED4 } \\
\text { anomaly }\end{array}$ & $\begin{array}{l}\text { GFED4 } \\
\text { SD }\end{array}$ & $\begin{array}{l}\text { ICARTT } \\
\text { anomaly }\end{array}$ & $\begin{array}{l}\text { ICARTT } \\
\text { SD }\end{array}$ & $\begin{array}{l}\text { Anomaly } \\
\text { altitude }\end{array}$ \\
\hline 29 June 2004 Caracas-Frankfurt & 32.6 & 33.2 & 44.4 & 2.4 & 43.0 & 2.3 & 43.6 & 2.4 & PBL \\
\hline 30 June 2004 Frankfurt-Washington & 52.5 & 34.0 & 36.6 & 9.1 & 25.4 & 6.6 & 23.5 & 5.9 & MT \\
\hline 22 July 2004 Douala-Paris & 117.1 & 24.2 & 43.5 & 20.0 & 55.0 & 27.2 & 72.4 & 42.3 & MT \\
\hline 23 July 2004 Frankfurt-Atlanta & 78.9 & 45.4 & 34.7 & 22.4 & 45.3 & 32.8 & 46.0 & 35.9 & MT \\
\hline 30 July 2008 Windhoek-Frankfurt & 72.9 & 41.9 & 33.0 & 19.2 & 42.8 & 26.0 & N/A & N/A & UT \\
\hline
\end{tabular}

In this study SOFT-IO is applied to all IAGOS CO observations, using ECMWF operational meteorological analysis and $3 \mathrm{~h}$ forecast fields and inventories of anthropogenic and biomass burning emissions available on the ECCAD portal. SOFT-IO outputs are evaluated first at the examples of case studies of anthropogenic and biomass burning pollution 
events. The evaluation is then extended statistically, for the entire 2003-2013 period, over 14 regions and 3 vertical layers of the troposphere.

The main results are the following:

- By calculating the contributions of recent emissions to the $\mathrm{CO}$ mixing ratio along the flight tracks, SOFTIO identifies the source regions responsible for the observed pollution events and is able to attribute such plumes to anthropogenic and/or biomass burning emissions.

- On average, SOFT-IO detects $95 \%$ of all observed CO plumes. In certain regions, detection frequency reaches almost $100 \%$.

- SOFT-IO gives a good estimation of the CO mixing ratio enhancements for the majority of the regions and the vertical layers. Mostly, the CO contribution is reproduced with a mean bias lower than $10-15 \mathrm{ppb}$ except for the measurements in the LT of central and southern Asia and in the UT of northern Asia, where emission inventories seem to be less accurate.

- CO anomalies calculated by SOFT-IO are very close to observations in the LT and UT, where most of the IAGOS data are recorded. Agreement is lower in the MT, possibly because of numerous thinner plumes of lower intensity (maybe linked to the methodology of the plume selection).

- SOFT-IO has less skill in modeling CO in extreme plume enhancements with biases higher than $50 \mathrm{ppb}$.

In its current version, SOFT-IO is limited by different parameters, such as inherent parameterization of the Lagrangian model, but also by input of external parameters such as meteorological field analysis and emission inventories. Sensitivity analyses were then performed using different meteorological analysis and emission inventories and are summarized as follows:

- Model results were not very sensitive to the resolution of the meteorological input data. Increasing the resolution from $1^{\circ}$ to $0.5^{\circ}$ resulted only in minor improvements. In contrast, using operational meteorological analysis allowed more accurate simulations than using ERA-Interim reanalysis data, perhaps due to the better vertical resolution of the former.

- Concerning anthropogenic emission sensitivity tests, results display regional differences depending on the emission inventory choice. Slightly better results are obtained using MACCity.

- Model results were not sensitive to biomass burning global inventories, with good results using either GFED 4 or GFAS v1.2. However, a regional emission inventory shows better results for few individual cases with high $\mathrm{CO}$ enhancements. There is a low sensitivity to parameterizing the altitude of fire emission injection, probably because events of fires injected outside of the PBL are rare or because IAGOS does not frequently sample of such events.

Using such $\mathrm{CO}$ calculations and partitioning makes it possible to link the trends in the atmospheric composition with changes in the transport pathways and/or changes of the emissions.

Data availability. SOFT-IO products will be made available through the IAGOS central database (http://iagos. sedoo.fr/\#L4Place) and are part of the ancillary products (https://doi.org/10.25326/3) (Sauvage et al., 2017a, b).

\section{The Supplement related to this article is available online at https://doi.org/10.5194/acp-17-15271-2017- supplement.}

Competing interests. The authors declare that they have no conflict of interest.

Acknowledgements. The authors would like to thank ECCAD project for providing emission inventories. The authors acknowledge the strong support of the European Commission, Airbus, and the airlines (Lufthansa, Air France, Austrian, Air Namibia, Cathay Pacific, Iberia and China Airlines so far) who have carried the MOZAIC or IAGOS equipment and performed the maintenance since 1994. In its last 10 years of operation, MOZAIC has been funded by INSU-CNRS (France), Météo-France, Université Paul Sabatier (Toulouse, France) and Research Center Jülich (FZJ, Jülich, Germany). IAGOS has been additionally funded by the EU projects IAGOS-DS and IAGOS-ERI. The MOZAIC-IAGOS database is supported by AERIS (CNES and INSU-CNRS). The former CNES-ETHER program funded this project.

Edited by: Robert Harley

Reviewed by: two anonymous referees

\section{References}

Barret, B., Sauvage, B., Bennouna, Y., and Le Flochmoen, E.: Upper-tropospheric $\mathrm{CO}$ and $\mathrm{O}_{3}$ budget during the Asian summer monsoon, Atmos. Chem. Phys., 16, 9129-9147, https://doi.org/10.5194/acp-16-9129-2016, 2016.

Beirle, S., Spichtinger, N., Stohl, A., Cummins, K. L., Turner, T., Boccippio, D., Cooper, O. R., Wenig, M., Grzegorski, M., Platt, U., and Wagner, T.: Estimating the $\mathrm{NO}_{x}$ produced by lightning from GOME and NLDN data: a case study in the Gulf of Mexico, Atmos. Chem. Phys., 6, 1075-1089, https://doi.org/10.5194/acp6-1075-2006, 2006. 
Boden, T. A., Marland, G., and Andres, R. J.: Global, Regional, and National Fossil-Fuel $\mathrm{CO}_{2}$ Emissions, Carbon Dioxide Information Analysis Center, Oak Ridge National Laboratory, US Department of Energy, Oak Ridge, Tenn., USA, https://doi.org/10.3334/CDIAC/00001_V2015, 2015.

Cammas, J.-P., Brioude, J., Chaboureau, J.-P., Duron, J., Mari, C., Mascart, P., Nédélec, P., Smit, H., Pätz, H.-W., Volz-Thomas, A., Stohl, A., and Fromm, M.: Injection in the lower stratosphere of biomass fire emissions followed by long-range transport: a MOZAIC case study, Atmos. Chem. Phys., 9, 5829-5846, https://doi.org/10.5194/acp-9-5829-2009, 2009.

Clark, H., Sauvage, B., Thouret, V., Nédélec, P., Blot, R., Wang, K.-Y., Smit, H., Neis, P., Petzold, A., Athier, G., Boulanger, D., Cousin, J.-M., Beswick, K., Gallagher, M., Baumgardner, D., Kaiser, J., Flaud, J.-M., Wahner, A., Volz-Thomas, A., and Cammas, J.-P.: The First Regular Measurements of Ozone, Carbon Monoxide and Water Vapour in the Pacific UTLS by IAGOS, Tellus B, 67, 28385, https://doi.org/10.3402/tellusb.v67.28385, 2015.

Cooper, O. R., Stohl, A., Trainer, M., Thompson, A. M., Witte, J. C., Oltmans, S. J., Morris, G., Pickering, K. E., Crawford, J. H., Chen, G., Cohen, R. C., Bertram, T. H., Wooldridge, P., Perring, A., Brune, W. H., Merrill, J., Moody, J. L., Tarasick, D., Nédélec, P., Forbes, G., Newchurch, M. J., Schmidlin, F. J., Johnson, B. J., Turquety, S., Baughcum, S. L., Ren, X., Fehsenfeld, F. C., Meagher, J. F., Spichtinger, N., Brown, C. C., McKeen, S. A., McDermid, I. S., and Leblanc, T.: Large upper tropospheric ozone enhancements above midlatitude North America during summer: In situ evidence from the IONS and MOZAIC ozone measurement network, J. Geophys. Res., 111, D24, https://doi.org/10.1029/2006JD007306, 2006.

Cristofanelli, P., Fierli, F., Marinoni, A., Calzolari, F., Duchi, R., Burkhart, J., Stohl, A., Maione, M., Arduini, J., and Bonasoni, P.: Influence of biomass burning and anthropogenic emissions on ozone, carbon monoxide and black carbon at the Mt. Cimone GAW-WMO global station (Italy, $2165 \mathrm{~m}$ a.s.1.), Atmos. Chem. Phys., 13, 15-30, https://doi.org/10.5194/acp-13-15-2013, 2013.

Damoah, R., Spichtinger, N., Forster, C., James, P., Mattis, I., Wandinger, U., Beirle, S., Wagner, T., and Stohl, A.: Around the world in 17 days - hemispheric-scale transport of forest fire smoke from Russia in May 2003, Atmos. Chem. Phys., 4, 13111321, https://doi.org/10.5194/acp-4-1311-2004, 2004.

Dentener, F., Kinne, S., Bond, T., Boucher, O., Cofala, J., Generoso, S., Ginoux, P., Gong, S., Hoelzemann, J. J., Ito, A., Marelli, L., Penner, J. E., Putaud, J.-P., Textor, C., Schulz, M., van der Werf, G. R., and Wilson, J.: Emissions of primary aerosol and precursor gases in the years 2000 and 1750 prescribed data-sets for AeroCom, Atmos. Chem. Phys., 6, 43214344, https://doi.org/10.5194/acp-6-4321-2006, 2006.

Ding, A., Wang, T., and $\mathrm{Fu}, \mathrm{C} .:$, Transport characteristics and origins of carbon monoxide and ozone in Hong Kong, South China, J. Geophys. Res.-Atmos., 118, 9475-9488, https://doi.org/10.1002/jgrd.50714, 2013.

Eastham, S. D. and Jacob, D. J.: Limits on the ability of global Eulerian models to resolve intercontinental transport of chemical plumes, Atmos. Chem. Phys., 17, 2543-2553, https://doi.org/10.5194/acp-17-2543-2017, 2017.

Elguindi, N., Clark, H., Ordonez, C., Thouret, V., Flemming, J., Stein, O., Huijnen, V., Moinat, P., Inness, A., Peuch, V.-H.,
Stohl, A., Turquety, S., Athier, G., Cammas, J.-P., and Schultz, M.: Current status of the ability of the GEMS/MACC models to reproduce the tropospheric $\mathrm{CO}$ vertical distribution as measured by MOZAIC, Geosci. Model Dev., 3, 501-518, http: //www.geosci-model-dev.net/3/501/2010/, 2010.

Freitas, S. R., Longo, K. M., Chatfield, R., Latham, D., Silva Dias, M. A. F., Andreae, M. O., Prins, E., Santos, J. C., Gielow, R., and Carvalho Jr., J. A.: Including the sub-grid scale plume rise of vegetation fires in low resolution atmospheric transport models, Atmos. Chem. Phys., 7, 3385-3398, https://doi.org/10.5194/acp7-3385-2007, 2007.

Giglio, S., Randerson, J. T., and Van der Werf, G. R.: Analysis of daily, monthly, and annual burned area using the fourthgeneration global fire emissions database (GFED4), J. Geophys. Res., 317-328, https://doi.org/10.1002/jgrg.20042, 2013.

Good, P., Giannakopoulos, C., O'Connor, F. M., Arnold, S. R., de Reus, M., and Schlager, H.: Constraining tropospheric mixing timescales using airborne observations and numerical models, Atmos. Chem. Phys., 3, 1023-1035, https://doi.org/10.5194/acp3-1023-2003, 2003.

Granier, C., Bessagnet, B., Bond, T., D’Angiola, A., Denier van der Gon, H., Frost, G., Heil, A., Kaiser, J., Kinne, S., Klimont, Z., Kloster, S., Lamarque, J.-F., Liousse, C., Masui, T., Meleux, F., Mieville, A., Ohara, T., Raut, J.-C., Riahi, K., Schultz, M., Smith, S., Thompson, A., van Aardenne, J., van der Werf, G., and van Vuuren, D.: Evolution of anthropogenic and biomass burning emissions of air pollutants at global and regional scales during the 1980-2010 period, Clim. Change, 109, 163-190, https://doi.org/10.1007/s10584-011-0154-1, 2011.

Granier, C., Damas, S., Liousse, C., Middleton, P., Mieville, A., Paulin, M., and Pignot, V.: The ECCAD Database: Emissions of Atmospheric Compounds \& Compilation of Ancillary Data, IGAC Newsletter, 18-20, 2012.

Gressent, A., Sauvage, B., Defer, E., Pätz, H. W., Thomas, K., Holle, R., Cammas, J.-P., Nédélec, P., Boulanger, D., Thouret, V., Volz-Thomas, A.: Lightning $\mathrm{NO}_{x}$ influence on large-scale $\mathrm{NO}_{y}$ and $\mathrm{O}_{3}$ plumes observed over the northern mid-latitudes, Tellus B, 66, 25544, https://doi.org/10.3402/tellusb.v66.25544, 2014.

Hanna, S. R.: Applications in Air Pollution Modeling, edited by: Nieuwstadt, F. T. M. and van Dop, H., in: Atmospheric Turbulence and Air Pollution Modelling, Atmospheric Sciences Library, vol 1., Springer, Dordrecht doi:https://doi.org/10.1007/978-94-010-9112-1_7, 1984.

Jacob, D. J.: Introduction to Atmospheric Chemistry, Princeton University Press, ISBN-13:978-0691001852, ISBN-10:0691001855, 1999.

Janssens-Maenhout, G., Petrescu, A. M. R., Muntean, M., and Blujdea, V.: Verifying Greenhouse Gas Emissions: Methods to Support International Climate Agreements, Greenhouse Gas Measurement and Management, 2010.

Kaiser, J. W., Heil, A., Andreae, M. O., Benedetti, A., Chubarova, N., Jones, L., Morcrette, J.-J., Razinger, M., Schultz, M. G., Suttie, M., and van der Werf, G. R.: Biomass burning emissions estimated with a global fire assimilation system based on observed fire radiative power, Biogeosciences, 9, 527-554, https://doi.org/10.5194/bg-9-527-2012, 2012.

Liu, J., Logan, J. A., Murray, L. T., Pumphrey, H. C., Schwartz, M. J., and Megretskaia, I. A.: Transport analysis and source attribution of seasonal and interannual variability of $\mathrm{CO}$ in the tropical 
upper troposphere and lower stratosphere, Atmos. Chem. Phys., 13, 129-146, https://doi.org/10.5194/acp-13-129-2013, 2013.

Logan, J. A., Prather, M. J., Wofsy, and Mcelroy, M. B.: Tropospheric Chemistry - A Global Perspective, J. Geophys. Res., 86, 7210-7254, 1981.

Marenco, A., Thouret, V., Nédélec, P., Smit, H., Helten, M., Kley, D., Karcher, F., Simon, P., Law, K., Pyle, J., Poschmann, G., Von Wrede, R., Hume, C., and Cook, T: Measurement of ozone and water vapor by Airbus in-service aircraft: The MOZAIC airborne program, An overview, J. Geophys. Res., 103, D19, https://doi.org/10.1029/98JD00977, 1998.

Mauzerall, D. L., Logan, J. A., Jacob, D. J., Anderson, B. E., Blake, D. R., Bradshaw, J. D., Heikes, B., Sachse, G. W., Singh, H., and Talbot, B.: Photochemistry in biomass burning plumes and implications for tropospheric ozone over the tropical South Atlantic, J. Geophys. Res., 103, 8401-8423, 1998.

Miyazaki, K., Eskes, H., Sudo, K., Boersma, K. F., Bowman, K., and Kanaya, Y.: Decadal changes in global surface $\mathrm{NO}_{x}$ emissions from multi-constituent satellite data assimilation, Atmos. Chem. Phys., 17, 807-837, https://doi.org/10.5194/acp-17-8072017, 2017.

Nédélec, P., Thouret, V., Brioude, J., Sauvage, B., Cammas, J. P., and Stohl, A.: Extreme CO concentrations in the upper troposphere over northeast Asia in June 2003 from the in situ MOZAIC aircraft data, Geophys. Res. Lett., 32, doi:10.1029/2005GL023141, 2005.

Nédélec, P., Cammas, J.-P., Thouret, V., Athier, G., Cousin, J.-M., Legrand, C., Abonnel, C., Lecoeur, F., Cayez, G., and Marizy, C.: An improved infrared carbon monoxide analyser for routine measurements aboard commercial Airbus aircraft: technical validation and first scientific results of the MOZAIC III programme, Atmos. Chem. Phys., 3, 1551-1564, https://doi.org/10.5194/acp3-1551-2003, 2003.

Nédélec, P., Blot, R., Boulanger, D., Athier, G., Cousin, J.-M., Gautron, B., Petzold, A., and Volz-Thomas, A.: Instrumentation on commercial aircraft for monitoring the atmospheric composition on a global scale: the IAGOS system, technical overview of ozone and carbon monoxide measurements, Tellus B, 67, 27791, doi:10.3402/tellusb.v67.27791, 2015.

Newell, R. E., Thouret, V., Cho, J. Y. N., Stoller, P., Marenco, A., and Smit, H. G. S.: Ubiquity of quasi-horizontal layers in the atmosphere, Nature, 398, 316-319, https://doi.org/10.1038/18642, 1999.

Paugam, R., Wooster, M., Atherton, J., Freitas, S. R., Schultz, M. G., and Kaiser, J. W.: Development and optimization of a wildfire plume rise model based on remote sensing data inputs - Part 2, Atmos. Chem. Phys. Discuss., https://doi.org/10.5194/acpd-159815-2015, 2015.

Paugam, R., Wooster, M., Freitas, S., and Val Martin, M.: A review of approaches to estimate wildfire plume injection height within large-scale atmospheric chemical transport models, Atmos. Chem. Phys., 16, 907-925, https://doi.org/10.5194/acp-16907-2016, 2016.

Petzold, A., Thouret, V., Gerbig, C., Zahn, A., Brenninkmeijer, C. A. M., Gallagher, M., Hermann, M., Pontaud, M., Ziereis, H., Boulanger, D., Marshall, J., Nédélec, P., Smit, H., G. J., Friess, U., Flaud, J.-M., Wahner, A., Cammas, J.-P., Volz-Thomas, A., and IAGOS team: Global-scale atmosphere monitoring by inservice aircraft - current achievements and future prospects of the European Research infrastructure IAGOS, Tellus B, 67, 28452, doi:10.3402/tellusb.v67.28452, 2015.

Pisso, I., Real, E., Law, K. S., Legras, B., Bousserez, N., Attié, J. L., and Schlager, H.: Estimation of mixing in the troposphere from Lagrangian trae gas reconstructions during long-range pollution plume transport, J. of Geophys. Res., 114, D19301, 2010.

Rémy, S., Veira, A., Paugam, R., Sofiev, M., Kaiser, J. W., Marenco, F., Burton, S. P., Benedetti, A., Engelen, R. J., Ferrare, R., and Hair, J. W.: Two global data sets of daily fire emission injection heights since 2003, Atmos. Chem. Phys., 17, 2921-2942, https://doi.org/10.5194/acp-17-2921-2017, 2017.

Rodean, H. C.: Stochastic Lagrangian Models of Turbulent Diffusion, vol. 26, American Meteorological Society, 1996.

Sauvage, B., Thouret, V., Cammas, J.-P., Gheusi, F., Athier, G., and Nédélec, P.: Tropospheric ozone over Equatorial Africa: regional aspects from the MOZAIC data, Atmos. Chem. Phys., 5, 311335, https://doi.org/10.5194/acp-5-311-2005, 2005.

Sauvage, B., V., Thouret, A. M., Thompson, J. C., Witte, J.-P., Cammas, P., Nédélec, and Athier, G.: Enhanced view of the "tropical Atlantic ozone paradox" and "zonal wave one" from the in situ MOZAIC and SHADOZ data, J. Geophys. Res., 111, D01301, https://doi.org/10.1029/2005JD006241, 2006.

Sauvage, B., Thouret, V., Cammas, J.-P., Brioude, J., Nédélec, P., and Mari, C.: Meridional ozone gradients in the African upper troposphere, Geophys. Res. Lett., 34, L03817, doi:2006GL028542, 2007a.

Sauvage, B., Martin, R. V., van Donkelaar, A., and Ziemke, J. R. Quantification of the factors controlling tropical tropospheric ozone and the South Atlantic maximum, J. Geophys. Res., 112, D11309, https://doi.org/10.1029/2006JD008008, 2007b

Sauvage, B., Martin, R. V., van Donkelaar, A., Liu, X., Chance, K., Jaeglé, L., Palmer, P. I., Wu, S., and Fu, T.-M.: Remote sensed and in situ constraints on processes affecting tropical tropospheric ozone, Atmos. Chem. Phys., 7, 815-838, https://doi.org/10.5194/acp-7-815-2007, 2007c.

Sauvage, B., Auby, A., and Fontaine, A.: SOFT-IO: SOft attribution using FlexparT and carbon monoxide emission inventories for In-situ Observation database, Aeris, https://doi.org/10.25326/2, 2017a.

Sauvage, B., Fontaine, A., and Boulanger, D.: IAGOS ancillary data: CO contributions dataset, Data set, Aeris, https://doi.org/10.25326/3, 2017 b.

Seibert, P. and Frank, A.: Source-receptor matrix calculation with a Lagrangian particle dispersion model in backward mode, Atmos. Chem. Phys., 4, 51-63, https://doi.org/10.5194/acp-4-512004, 2004.

Staudt, A. C., Jacob, D. J., Logan, J. A., Bachiochi, D., Krishnamurti, T. N., and Sachse, G. W.: Continental sources, transoceanic transport, and interhemispheric exchange of carbon monoxide over the Pacific, J. Geophys. Res., 106, 32571-32590, 2001.

Stein, O., Schultz, M. G., Bouarar, I., Clark, H., Huijnen, V., Gaudel, A., George, M., and Clerbaux, C.: On the wintertime low bias of Northern Hemisphere carbon monoxide found in global model simulations, Atmos. Chem. Phys., 14, 9295-9316, https://doi.org/10.5194/acp-14-9295-2014, 2014.

Stohl, A., Hittenberger, M., and Wotawa, G.: Validation of the Lagrangian particle dispersion model FLEXPART against large scale tracer experiments, Atmos. Environ., 32, 4245-4264, 1998. 
Stohl, A. and Thomson, D. J.: A density correction for Lagrangian particle dispersion models, Bound. Lay. Meteorol., 90, 155-167, 1999.

Stohl, A., Eckhardt, S., Forster, C., James, P., and Spichtinger, N.: On the pathways and timescales of intercontinental air pollution transport, J. Geophys. Res., 107, 4684, doi:10.1029/2001JD001396, 2002.

Stohl, A., Forster, C., Eckhardt, S., Spichtinger, N., Huntrieser, H., Heland, J., Schlager, H., Wilhelm, S., Arnold, F., and Cooper, O.: A backward modeling study of intercontinental pollution transport using aircraft measurements, J. Geophys. Res., 108, 4370, doi:10.1029/2002JD002862, 2003.

Stohl, A., Forster, C., Frank, A., Seibert, P., and Wotawa, G.: Technical note: The Lagrangian particle dispersion model FLEXPART version 6.2, Atmos. Chem. Phys., 5, 2461-2474, https://doi.org/10.5194/acp-5-2461-2005, 2005.

Stohl, A., Aamaas, B., Amann, M., Baker, L. H., Bellouin, N., Berntsen, T. K., Boucher, O., Cherian, R., Collins, W., Daskalakis, N., Dusinska, M., Eckhardt, S., Fuglestvedt, J. S., Harju, M., Heyes, C., Hodnebrog, Ø., Hao, J., Im, U., Kanakidou, M., Klimont, Z., Kupiainen, K., Law, K. S., Lund, M. T., Maas, R., MacIntosh, C. R., Myhre, G., Myriokefalitakis, S., Olivié, D., Quaas, J., Quennehen, B., Raut, J.-C., Rumbold, S. T., Samset, B. H., Schulz, M., Seland, $\varnothing$, Shine, K. P., Skeie, R. B., Wang, S., Yttri, K. E., and Zhu, T.: Evaluating the climate and air quality impacts of short-lived pollutants, Atmos. Chem. Phys., 15, 10529-10566, https://doi.org/10.5194/acp-15-105292015, 2015.

Stroppiana, D., Brivio, P. A., Grégoire, J.-M., Liousse, C., Guillaume, B., Granier, C., Mieville, A., Chin, M., and Pétron, G.: Comparison of global inventories of $\mathrm{CO}$ emissions from biomass burning derived from remotely sensed data, Atmos. Chem. Phys., 10, 12173-12189, https://doi.org/10.5194/acp-1012173-2010, 2010.

Tanimoto, H., Ohara, T., and Uno, I.: Asian anthropogenic emissions and decadal trends in springtime tropospheric ozone over Japan: 1998-2007, Geophys. Res. Lett., 36, https://doi.org/10.1029/2009GL041382, 2009.

Taylor, K. E.: Summarizing multiple aspects of model performance in a single diagram, J. Geophys. Res., 106, 7183-7192, 2001.

Tressol, M., Ordonez, C., Zbinden, R., Brioude, J., Thouret, V., Mari, C., Nédélec, P., Cammas, J.-P., Smit, H., Patz, H.-W., and Volz-Thomas, A.: Air pollution during the 2003 European heat wave as seen by MOZAIC airliners, Atmos. Chem. Phys., 8, 2133-2150, https://doi.org/10.5194/acp-8-2133-2008, 2008.

Turquety, S., Logan, J. A., Jacob, D. J., Hudman, R. C., Leung, F. Y., Heald, C. L., Yantosca, R. M., Wu, S., Emmons, L. K., Edwards, D. P., and Sachse, G. W.: Inventory of boreal fire emissions for North America in 2004: Importance of peat burning and pyroconvective injection, J. Geophys. Res., 112, D12S03, doi:10.1029/2006JD007281, 2007.

van der Werf, G. R., Randerson, J. T., Giglio, L., Collatz, G. J., Mu, M., Kasibhatla, P. S., Morton, D. C., DeFries, R. S., Jin, Y., and van Leeuwen, T. T.: Global fire emissions and the contribution of deforestation, savanna, forest, agricultural, and peat fires (1997-2009), Atmos. Chem. Phys., 10, 11707-11735, https://doi.org/10.5194/acp-10-11707-2010, 2010.

Tanimoto, H., Ohara, T., and Uno, I.: Asian anthropogenic emissions and decadal trends in springtime tropospheric ozone over Japan: 1998-2007, Geophys. Res. Lett., 36, L23802, https://doi.org/10.1029/2009GL041382, 2009.

Thouret, V., Cho, J. Y. N., Newell, R. E., Larenco, A., and Smit, H. G. J.: General characteristics of tropospheric trace constituent layers observed in the MOZAIC program, J. Geophys. Res., 105, 17379-17392, https://doi.org/10.1029/2000JD900238, 2000.

Thouret, V., Cammas, J.-P., Sauvage, B., Athier, G., Zbinden, R., Nédélec, P., Simon, P., and Karcher, F.: Tropopause referenced ozone climatology and inter-annual variability (1994-2003) from the MOZAIC programme, Atmos. Chem. Phys., 6, 1033-1051, https://doi.org/10.5194/acp-6-1033-2006, 2006.

Vay, S. A., Choi, Y., Vadrevu, K. P., Blake, D. R., Tyler, S. C., Wisthaler, A., Hecobian, A., Kondo, Y., Diskin, G. S., Sachse, G. W., Woo, J.-H., Weinheimer, A. J., Burkhart, J. F., Stohl, A., and Wennberg, P. O.: Patterns of $\mathrm{CO}_{2}$ and radiocarbon across high northern latitudes during International Polar Year 2008, J. Geophys. Res. 116, D14301, https://doi.org/10.1029/2011JD015643, 2011.

Wang, X., Wang, Y., Hao, J., Kondo, Y., Irwin, M., Munger, J. W., and Zhao, Y.: Top-down estimate of China's black carbon emissions using surface observations: sensitivity to observation representativeness and transport model error, J. Geophys. Res., 118, 5781-5795, https://doi.org/10.1002/jgrd.50397, 2013.

Wen, D. Y., Lin, J. C., Millet, D. B., Stein, A. F., and Draxler, R. R.: A backward-time stochastic Lagrangian air quality model, Atmos. Environ, 54, 373-386, 2012.

Yamasoe, M. A., Sauvage, B., Thouret, V., Nédélec, P., Le Flochmoen, E., and Barret, B.: Analysis of tropospheric ozone and carbon monoxide profiles over South America based on MOZAIC/IAGOS database and model simulations, Tellus B, 67, 27884, doi:10.3402/tellusb.v67.27884, 2015.

Yashiro, H., Sugawara, S., Sudo, K., Aoki, S., and Nakazawa, T.: Temporal and spatial variations of carbon monoxide over the western part of the Pacific Ocean, J. Geophys. Res., 114, D08305, https://doi.org/10.1029/2008jd010876, 2009.

Zhang, Y. Q., Liu, H. Y., Crawford, J. H., Considine, D. B., Chan, C. Y., Oltmans, S. J., and Thouret, V.: Distribution, variability and sources of tropospheric ozone over south China in spring: Intensive ozonesonde measurements at five locations and modeling analysis, J. Geophys. Res., 117, D12304, doi:10.1029/2012JD017498, 2012.

Zhang, L., Henze, D. K., Grell, G. A., Carmichael, G. R., Bousserez, N., Zhang, Q., Torres, O., Ahn, C., Lu, Z., Cao, J., and Mao, Y.: Constraining black carbon aerosol over Asia using OMI aerosol absorption optical depth and the adjoint of GEOS-Chem, Atmos. Chem. Phys., 15, 10281-10308, https://doi.org/10.5194/acp-1510281-2015, 2015. 